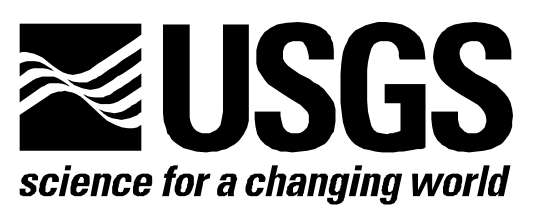

\title{
GIS SURFACE EFFECTS ARCHIVE OF UNDERGROUND NUCLEAR DETONATIONS CONDUCTED AT YUCCA FLAT AND PAHUTE MESA, NEVADA TEST SITE, NEVADA
}

By Dennis N. Grasso

Open-File Report 01-272

Prepared in cooperation with the

U.S. DEPARTMENT OF ENERGY

NEVADA OPERATIONS OFFICE

(Interagency Agreement DE-AI08-96NV11967)

2001

This report is preliminary and has not been reviewed for conformity with U.S. Geological Survey editorial standards or with the North American Stratigraphic Code. Any use of trade, firm, or product names is for descriptive purposes only and does not imply endorsement by the U.S. Government.

\section{U.S. DEPARTMENT OF THE INTERIOR U.S. GEOLOGICAL SURVEY}

Federal Center, Denver, Colorado 80225 


\section{TABLE OF CONTENTS}

\section{Section 1-Introduction}

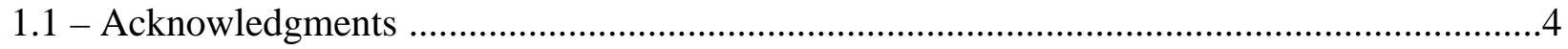

1.2 - Nuclear Testing at the Nevada Test Site ………............................................................

1.3 - A Brief History of Surface Effects Investigations.............................................................6

\section{Section 2-Surface Effects}

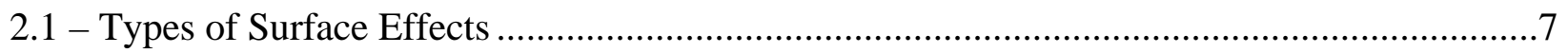

2.2 - Surface Effects Mapping at the Nevada Test Site …………..............................................

\section{Section 3-The GIS Surface Effects Map Archive}

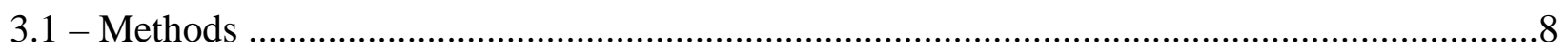

3.2 - Converting Maps from Analog to Digital Format ..............................................................8

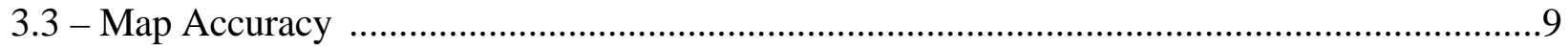

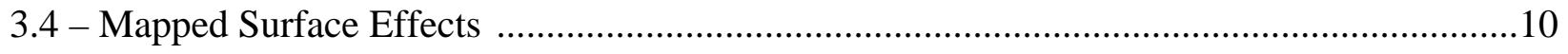

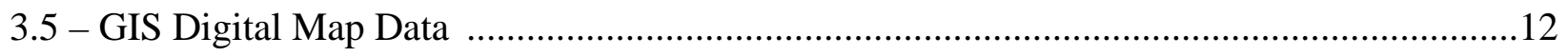

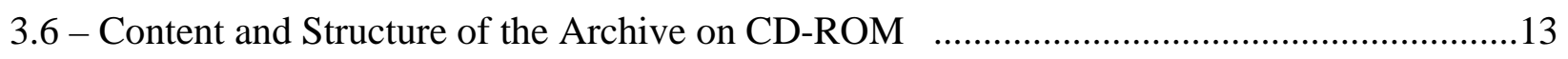

3.7 - View the Maps and Explore the Databases on CD-ROM ………......................................15

\section{Section 4}

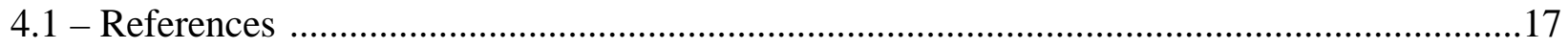

4.2 - Figures

Figure 1. Location map of detonation sites and mapped surface effects, Nevada Test Site,

Nevada ........................................................................................................ 18

Figure 2. Shaded relief maps of north-central Yucca Flat, Nevada .....................................19

Figure 3. Surface effects caused by the Latir (U-4d) detonation, Yucca Flat, Nevada .......20

Figure 4. GIS composite surface effects map of Latir (U-4d) and surrounding detonation sites, Yucca Flat, Nevada

Figure 5. Aerial photograph of collapse sink at Portmanteau (U-2ax) detonation site, Yucca Flat, Nevada

Figure 6. Aerial photograph of collapse sink at Commodore (U-2am) detonation site, Yucca Flat, Nevada

Figure 7. GIS surface effects map of the Delamar (U-20at) detonation site, Pahute Mesa, Nevada

Figure 8. GIS composite surface effects map of Carpetbag (U-2dg) and surrounding detonation sites, Yucca Flat, Nevada 
4.3 - Tables

Table 1. Number of detonations, boreholes, and surface effects maps for underground nuclear tests conducted within the Yucca Flat and Pahute Mesa Testing Areas, Nevada Test

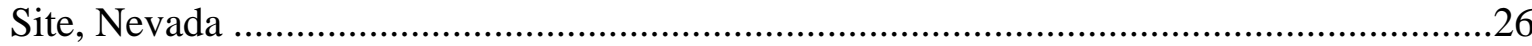

Table 2. Surface effects summary statistics for the Yucca Flat and Pahute Mesa Testing Areas

Table 3. Content and description of attributes for the GIS surface effects map databases ..28

Table 4. Content and description of attributes for the GIS surface effects sites database....29

Table 5. Content and structure of the GIS Surface Effects Map Archive on CD-ROM ......31

4.4 - Glossary .33

CD-ROM: GIS Surface Effects Map Archive (Accompanies this pamphlet)

Plate 1: Pahute Mesa Surface Effects Map. (Accompanies this pamphlet) 


\title{
GIS SURFACE EFFECTS ARCHIVE OF UNDERGROUND NUCLEAR DETONATIONS CONDUCTED AT YUCCA FLAT AND PAHUTE MESA, NEVADA TEST SITE, NEVADA
}

\author{
SECTION 1: INTRODUCTION
}

\subsection{Acknowledgments}

This report presents a new comprehensive, digital archive of more than 40 years of geologic surface effects maps produced at individual detonation sites throughout the Yucca Flat and Pahute Mesa nuclear testing areas of the Nevada Test Site, Nye County, Nevada. The Geographic Information System (GIS) surface effects map archive on CD-ROM (this report) comprehensively documents the surface effects of underground nuclear detonations conducted at two of the most extensively used testing areas of the Nevada Test Site.

Between 1951 and 1992, numerous investigators of the U.S. Geological Survey, the Los Alamos National Laboratory, the Lawrence Livermore National Laboratory, and the Defense Threat Reduction Agency meticulously mapped the surface effects caused by underground nuclear testing. Their work documented the effects of more than seventy percent of the underground nuclear detonations conducted at Yucca Flat and all of the underground nuclear detonations conducted at Pahute Mesa. Garcia (1997, p. 3) summarizes the field and laboratory procedures they used and graciously acknowledges their painstaking efforts:

Surface effects mapping itself is a time consuming and tedious task, but one that has been completed with considerable attention to detail. Surface effects documentation was pioneered by F.A. McKeown and F.N. Houser in the early 1960's. Many other USGS geologists have been involved in the process including F.M. Byers Jr., H.R. Covington, D.D. Dickey, G.L. Dixon, M.N. Garcia, E.C. Jenkins, Florian Maldonado, P.P. Orkild, T.L. Prather, R.P. Snyder, R.R. Spengler, Susan Steele Wier, and W.S. Twenhofe. Geologists from the National Laboratories included Brian Allen, Anne Cavazos, Sigmund Drellack, Jose Gonzales, Ward Hawkins, Richard McArthur, Lawrence McKague, William McKinnis, Lance Prothro, William Davies, Casey Schmidt, Pete Thompson, Dean Townsend, and Margaret Townsend. Their combined mapping efforts and reports have documented surface effects at the Nevada Test Site for the past 40 plus years.

The most recent cooperative endeavor between the U.S. Geological Survey (USGS) and the U.S. Department of Energy (DOE) involved the compilation and preservation of these original surface effects maps into a comprehensive digital map archive. This work was performed under Interagency Agreement DE-AI08-96NV11967. The GIS surface effects archive preserves more than 40 years of maps of Yucca Flat and Pahute Mesa, and provides these in readily accessible formats for analysis, mapping, and management activities.

The many long hours of preparing digital reproductions of the original surface effects maps for this new GIS map archive may not have been realized without the persistent efforts of Bonnie Thompson and Martha Garcia, USGS, the gracious support of Steve Leedom, DOE, and the meticulous assistance on Pahute Mesa by Harry Covington. I thank you and the many others who 
directly and indirectly supported this project. This report and CD-ROM map archive will preserve the arduous achievements of those who spent countless hours to more fully understand the effects of underground nuclear testing at the Nevada Test Site.

\section{$1.2 \quad$ Nuclear Testing at the Nevada Test Site}

The Nevada Test Site (NTS) was established in 1951 as a continental location for testing nuclear devices (Allen and others, 1997, p. 3). Originally known as the "Nevada Proving Ground," the NTS hosted 928 nuclear detonations, of which 828 were conducted underground (U.S. Department of Energy, 1994). Principal testing areas of the NTS included: (1) Yucca Flat, (2) Pahute Mesa, (3) Rainier Mesa including Aqueduct Mesa, and (4) Frenchman Flat. Underground detonations at Yucca Flat and Pahute Mesa were typically emplaced in vertical drill holes (shafts); though, several were tunnel emplacements and some were crater emplacements. Of the four principal testing areas, Yucca Flat was the most extensively used, hosting 658 underground tests (747 detonations) located at 719 individual sites (Allen and others, 1997, p. 3-4). At Pahute Mesa, 85 underground detonations were conducted at 84 individual sites. The Pahute Mesa testing area was principally used when special test conditions, such as a large depthof-burial within volcanic test medium, or a "quiet" location away from other testing areas, were required for the underground nuclear tests (Harry Covington, personal commun. 2000).

Figure 1 shows the locations of underground nuclear detonations and mapped surface effects sites at the NTS. As illustrated, the majority of detonations were conducted within the Yucca Flat and Pahute Mesa testing areas. Table 1 lists the number of underground detonations conducted, the number of boreholes utilized, and the number of detonations mapped for surface effects within the Yucca Flat and Pahute Mesa testing areas, listed by NTS Operational Area.

The first nuclear detonation at the NTS was Uncle, conducted on November 29, 1951 as a crater type, weapons effects experiment in Area 10 of Yucca Flat (or Yucca Valley, as it is also known). The first "deep" underground detonation was Pascal-A (U-3j), conducted on July 26, 1957 as a shaft type, safety experiment in Area 3 of Yucca Flat at a depth of $152 \mathrm{~m}$ (499 ft) in an uncased (unstemmed) borehole (Allen and others, 1997, p. 3). At Pahute Mesa, the first underground nuclear detonation was Palanquin (U-20k), conducted on April 14, 1965 as a crater type, Plowshare experiment in Area 20 at a depth of $86 \mathrm{~m}(281 \mathrm{ft})$. In addition, the first Joint Verification Experiment between the United States and the Union of Soviet Socialist Republics was conducted at Pahute Mesa with the detonation of Kearsarge (U-19ax) on August 17, 1988 at a depth of $616 \mathrm{~m}(2,020 \mathrm{ft})$.

Nearly 41 years after the first nuclear test at NTS in 1951, the last weapons related experiment was conducted in Area 3 of Yucca Flat by the detonation of Divider (U-3mL) on September 23, 1992, just prior to the signing of a one-year moratorium on underground nuclear testing by President Bush in late 1992. Subsequently, the newly elected President Clinton extended this moratorium and later signed the Comprehensive Nuclear Test Ban Treaty, which prohibits all underground nuclear testing.

Allen and others (1997) provide detailed descriptions of underground nuclear testing at the NTS from 1951 to 1992, and furnish a comprehensive summary of the environmental effects of 
testing. Much of the nomenclature and descriptions of surface effects presented in this report were adopted from Allen and others (1997) and Garcia (1997).

\subsection{A Brief History of Surface Effects Investigations}

The USGS became involved with the nuclear testing program in 1957 as part of an aggressive effort to map the geology of the NTS at a scale of 1:24,000 (Garcia, 1997). This mapping effort not only provided the first detailed geologic maps of the area, but also gave scientists an opportunity to explore the containment characteristics of the geologic environment. Carothers (1995), for example, discusses how the geologic environment became a test parameter for nuclear testing. These early experiments revealed that geology and hydrology were important site-placement characteristics, and conversely, advanced our understanding of the geology of the NTS. Supported by the U.S. Atomic Energy Commission (AEC), the U.S. Energy Research and Development Administration (ERDA), and the U.S. Department of Energy (DOE), the USGS began an extensive research program to evaluate the geophysical, hydrological, and geological environments of the NTS. One component of this work involved mapping the surface effects caused by underground nuclear testing.

Post-detonation surface effects maps were produced using field and aerial-photo mapping techniques and published in several USGS Technical Letter reports. Features mapped included surface cracks; collapse sinks (and craters); fault movements; pressure ridges; and reactivated features. Garcia (1997), in what has informally become known as a "How-To Publication" on surface effects mapping, explains in detail the procedures used to prepare these maps. After each detonation, a final "crack map," as they are often called, was prepared in ink on stable-base Mylar drafting film for use in USGS publications and reports. These final crack maps were ultimately stored by the USGS in map files at the Denver Federal Center in Lakewood, Colorado.

The latest phases of surface effects map preparation by the USGS are reported on in this report, and in a prior report on Yucca Flat by the author (Grasso, 2000). In October 1997, a pilot project was implemented to evaluate methods for storing (archiving) the original crack maps in a more permanent and accessible format. A Geographic Information System was used because of its abilities to store map data with associated attribute (database) information, and because GIS provides methods to easily query, retrieve, update, and display these data as needed. Simply stated, the goals of this project were: (1) to reproduce the original surface effects maps in digital format so that they could be directly used for various computer-aided research, management, and readiness activities, and (2) to preserve, in a permanent digital archive, the surface effects maps that were so painstaking produced for nuclear tests conducted at the NTS.

This report summarizes the actions taken to address these goals and presents a comprehensive collection of GIS surface effects maps on CD-ROM for two of the most extensively used testing areas of the NTS. These GIS maps compose a digital map archive that represents more than 40 years of surface effects mapping at Yucca Flat, and nearly 30 years of surface effects mapping at Pahute Mesa. Additionally, this report includes a new large-scale (1:24,000), composite GIS surface effects map of Pahute Mesa. This map, which is presented as Plate 1, is similar to that previously published for Yucca Flat (Grasso, 2000; Plate 1), in that it is a comprehensive surface 
effects map showing the new GIS digital surface effects for all detonations conducted within the Pahute Mesa testing area.

\section{SECTION 2: SURFACE EFFECTS}

\subsection{Types of Surface Effects}

Allen and others (1997) classify surface effects at the NTS as geologic and hydrologic effects, ecological effects, and cultural-feature effects. The GIS surface effects map archive (this report) contains maps showing the geologic surface effects of underground nuclear testing and a detailed database of detonation sites and related surface effects map information. The surface effects maps present such features as collapse sinks, craters, cracks (fractures), fault movements, and pressure ridges that were produced by underground nuclear testing. The formation of these features is dependent upon many factors including the lithology and structure of the surface material, as well as the yield and depth of burial (DOB) of the nuclear device (Garcia, 1997). Definitions of these features are given in the Glossary of this report. Table 2 lists the types of surface effects mapped at Yucca Flat and Pahute Mesa and provides summary statistics of these features as contained in the GIS surface effects map archive.

The terminology used to describe surface effects was adopted from that presented by Allen and others (1997), Garcia (1997), and Covington (1987). For further information and illustrations of the surface effects produced by underground nuclear testing at the NTS, the reader is referred to Allen and others (1997).

\subsection{Surface Effects Mapping at the Nevada Test Site}

Surface effects mapping was initiated by the USGS in the 1950's and continued by the Los Alamos National Laboratory in 1977, the Lawrence Livermore National Laboratory in 1980, and the Defense Nuclear Agency (now the Defense Threat Reduction Agency) in 1982 (Garcia, 1997). To document the effects of testing, investigators from these agencies produced a surface effects map shortly following each underground nuclear detonation. The timing of these activities was critical because post-detonation weather conditions and construction activities would often quickly destroy any resultant surface features.

Surface effects maps were produced using field mapping, stereoscopic aerial photography, and photogrammetric techniques (Garcia, 1997). Aerial photographs were taken of a site both before and after a detonation to accurately document the explosion-induced surface effects. Postdetonation field mapping on pre-detonation photographs provided comprehensive documentation of any new surface effects caused by the detonation and revealed the presence of any reactivated surface effects (i.e., movements on pre-existing features). A second map was subsequently produced using the post-detonation aerial photographs and a photogrammetric plotter. The two maps were compared and any differences were checked in the field. Lastly, a final composite map was produced on stable-base, Mylar drafting film at a scale of 1:12,000 or larger. From these original Mylar surface effects maps, paper copies were made for use in reports. 


\section{SECTION 3: THE GIS SURFACE EFFECTS MAP ARCHIVE}

\subsection{Methods}

Surface effects mapping was performed for 530 of the 747 underground nuclear detonations conducted at Yucca Flat between November 29, 1951 (Uncle) and September 23, 1992 (Divider), and all 85 detonations conducted at Pahute Mesa between April 14, 1965 (Palanquin) and March 26, 1992 (Junction). Not all of these 615 detonations (Table 1) produced surface effects. Those that did not are identified in the sites database and on maps as "Mapped-no surface effects" because mapping activities were conducted, but no observable surface effects were identified. Additionally, some multiple detonation tests were conducted within the same borehole; thus, a single surface effects map may show the resultant effects of multiple detonations. As a result, the archive contains 486 surface effects maps for those tests that produced identifiable surface effects at Yucca Flat, and 84 surface effects maps for those conducted at Pahute Mesa. At Pahute Mesa, only one detonation (Buteo) did not produce identifiable surface effects.

The earliest surface effects maps commonly showed only of a simple outline of the sink (or crater) produced by the detonation. Examples of these are Uncle (Operation Jangle, 1951) and Ess (Operation Teapot, 1955) in Area 10; and Fisher (U-3ah; 1961), Ringtail (U-3ak; 1961), and Stoat (U-3ap; 1962) in Area 3 at Yucca Flat (Grasso, 2000; Plate 1). The first detailed surface effects map was produced for the 1962 Stillwater (U-9c) detonation in Area 9. This map not only showed the collapse sink, but also the surface cracks produced by the detonation along the nearby Yucca Fault Zone. When testing began at Pahute Mesa in 1965, detailed surface effects mapping had become routine, and continued to increase in complexity and accuracy. Since the mid1960's, the surface effects maps produced for both Yucca Flat and Pahute Mesa showed, in considerable detail, the collapse sinks and complex patterns of surface cracks, faults, and pressure ridges produced by the detonations near surface ground zero (SGZ) and along nearby fault zones. For those tests that produced faults with measured vertical displacements, the surface effects archive contains bar-and-ball symbol maps used to locate and label these features. There are bar-all-ball symbol themes in the archive for 85 detonation sites at Yucca Flat and 58 detonation sites at Pahute Mesa where displacements were measured along faults.

\subsection{Converting Maps from Analog to Digital Format}

The GIS surface effects map archive on CD-ROM contains an exact digital reproduction of the original, post-detonation maps produced for detonations conducted at the Yucca Flat and Pahute Mesa testing areas. These digital maps were created by scanning, georeferencing, and manually digitizing each original Mylar map. The completed digital maps were then assembled into a comprehensive GIS data archive for these testing areas.

The original Mylar maps were scanned at a resolution of 300-600 dots-per-inch to preserve map detail and accuracy. One-by-one, each scanned map was georeferenced to a common map coordinate system using 4 to 12 ground control (reference) points placed at known grid coordinates. A new raster-based, georeferenced map was then produced by resampling the map, pixel-by-pixel, to the Nevada State Plane (Central, in feet), North American Datum 1927 
(NAD27) coordinate system using a bilinear algorithm applied to the ground control points. A pixel size of 0.5 or 1.0 meter was used for large-scale $(1: 6,000)$ or small-scale $(1: 12,000)$ maps. The final map was then inserted into the GIS mapping program as a reference map from which the detonation's surface effects could be digitized and convert to a vector-based format.

Figure 3(A) shows a georeferenced, raster-based copy of the original Mylar surface effects map that was produced for the Latir (U-4d) detonation. Figure 3(B) shows the final GIS vector-based map that was produced by digitizing the original Mylar map.

Digitizing refers to the drawing (or tracing) of points, lines, and polygons from a reference map. While often done using a digitizing tablet, the operator has little control over the original scale of the map, and subsequently, the resolution and accuracy of the digitizing process. Another method of digitizing, which was implemented and perfected for this project, is to digitize on-screen from a georeferenced, raster-based reproduction of the original map. This approach allows the operator to zoom in to very large map scales; thus, controlling not only the resolution and accuracy of digitizing, but also the placement of the line segments (arcs and nodes) that comprise the various surface effects and symbols shown on the map.

The surface effects maps produced for Yucca Flat and Pahute Mesa were digitized on-screen at very large scales. For most areas, a digitizing scale of 1:500 (1 inch equals 42 feet) to 1:1,200 ( 1 inch equals 100 feet) was used. For areas containing very complex surface effects, however, a digitizing scale as large as 1:50 (1 inch equals $4.2 \mathrm{feet}$ ) was necessary. As part of the digitizing process, each map element (surface effects feature) was attributed (identified) with such unique information as site number, feature type, feature length, and source map information. These spatial and attribute data were then combined into a comprehensive set of GIS map files and related databases for the Yucca Flat and Pahute Mesa surface effects map archive. Table 2 lists summary statistics for the various surface effects features that comprise the archive.

The GIS surface effects archive enables the user to easily query and retrieve map and attribute information, and to prepare individual surface effects maps or composite surface effects maps of multiple detonation sites. The attribute information contained in the GIS surface effects maps and sites databases (Tables 3 and 4) provide the real power behind the archive. Using these databases, various types of maps can be prepared. The GIS surface effects map of U-4d (Fig. 3B) is an example of an individual site map produced from map data contained in the archive. Similarly, the GIS composite surface effects map of U-4d and surrounding sites (Fig. 4) is an example map of multiple detonation sites. These maps clearly illustrate the complex pattern of surface effects produced by underground nuclear testing and the abundance of detailed map information that were produced for this part of Yucca Flat during the 20-year period 1966 to 1986 . However, these maps represent only a small portion of the abundant map data that are now stored in digital format as part of the GIS surface effects map archive of Yucca Flat and Pahute Mesa.

\subsection{Map Accuracy}

The accuracy of the digital surface effects maps is equivalent to that of the originals. That is to say, the methods used to transform the original analog maps to digital format yielded very precise results. One way to quantify this reproduction accuracy is to compare the locations of control 
points on the digital map with their actual, on-the-ground locations. The horizontal distance between these locations is referred to as residual error. Measures of residual error at ground control points during the production of these maps revealed that the scanned and georeferenced maps have maximum residual errors of approximately 1.0 meter. In some cases, however, this error may be as large as 3 meters for some of the oldest and most poorly persevered maps.

\subsection{Mapped Surface Effects}

Explosion-induced surface effects mapped at Yucca Flat and Pahute Mesa consist primarily of collapse sinks, cracks, faults, and pressure ridges. Each underground nuclear detonation produced a unique number and pattern of surface effects. The magnitude and complexity of these features are related to the size and depth of the detonation, and to such site characteristics as underlying sediment or rock type, the geologic structure of the site, and other geologic and landscape factors. McKeown and Dickey (1967, p. 3), for example, reported the following about the Nash (U-2ce) detonation near the western border of Area 2 in Yucca Flat:

The Nash explosion at the U-2ce site produced a steep-walled sink, as did other explosions in this immediate area. The steeper walls of the sinks in this part of Yucca Valley as compared to other areas in the valley is believed to be due to better cementation and greater strength of the alluvium. Most of the fractures produced by the Nash explosion are radial and tangential to ground zero.

In addition to detonation and site characteristics, mapped surface effects may also differ from site-to-site and area-to-area depending on the emphasis of the mapping program and the agenda of the agency under which these maps were produced during different operational phases of the surface effects mapping program. As noted above, early mapping efforts focused only on the collapse sinks and craters produced by the detonations, whereas later mapping activities focused more thoroughly on the intricate patterns of fractures, pressure ridges, and fault movements that were produced by each detonation.

The GIS surface effects map archive includes a collection of more than 40 years of maps. A list of feature types used for these digital maps is given in Table 2. These are the attribute codes (or categories) for the digital surface effects. They allow groups of similar surface effects to be uniquely identified, selected, and displayed. By far, cracks (i.e., cracks and cracks within sinks) are the most prevalent surface effects type mapped at both Yucca Flat and Pahute Mesa with a cumulative length of 1,888 and $657 \mathrm{~km}$ (1,173 and $408 \mathrm{mi}$ ), respectively (Table 2). The longest mapped features at both testing areas are faults, specifically large named faults, with maximum single feature (continuous) lengths of 2,389 $\mathrm{m}(7,837 \mathrm{ft})$ for a fault within the Yucca Fault Zone at Yucca Flat, and 4,836 m (15,865 ft) for the Boxcar Fault associated with the Colby (U-20aa) detonation at Pahute Mesa. The collapse sinks, which are produced at SGZ, are probably the most visually impressive in the field and on the surface effects maps (Fig. 2). The largest sinks were produced by the Oscuro (U-7z) detonation in Area 7 at Yucca Flat and the Boxcar (U-20i) detonation in Area 20 at Pahute Mesa. These sinks measure 1,335 m (4,379 ft) and $986 \mathrm{~m}$ $(3,236 \mathrm{ft})$ in circumference, respectively (Table 2$)$. 
Descriptions of some of the most prominent surface effects mapped at Yucca Flat and Pahute Mesa are given in the following sections. Examples are presented for Pahute Mesa and illustrated on Plate 1. For all detonations mapped at Pahute Mesa (Plate 1) there are 16,827 individual surface effects having a combined length of $915.6 \mathrm{~km}$ (568.9 mi). A similar map publication is also available for Yucca Flat (Grasso, 2000; Plate 1). For detonations mapped at Yucca Flat there are 55,901 individual surface effects having a combined length of 2,397.1 km (1,489.5 mi). The GIS surface effects map archive on CD-ROM (this report) contains all of the surface effects maps and databases for both the Pahute Mesa and Yucca Flat testing areas.

\subsubsection{Collapse Sinks:}

Collapse sinks form when the collapse of rock fragments into the cavity created by the explosion extends to the surface (Houser, 1970). Sinks are commonly circular to elliptical in shape, as seen in map view, and form at or slightly offset from SGZ depending on rock type and structure. Some sinks have distinctive vertical edges and are quite deep, while others slope gently inward to a shallow central depression. Aerial photographs of the steep-sided collapse sinks produced by the Portmanteau (U-2ax) detonation (Fig. 5) and the Commodore (U-2am) detonation (Fig. 6) at Yucca Flat show the distinctive edges and steep walls of these sinks shortly after detonation. At Pahute Mesa, shallow-depression-type sinks were produced by the Halfbeak (U-19b) detonation (Snyder, 1971) and the Hornitos (U-20bc) detonation, whereas a somewhat steeper-sided sink was produced by the Boxcar (U-20i) detonation (Snyder, 1971). Additionally, a "cookie cutter" sink with short vertical walls was produced by the Delamar (U-20at) detonation, and offset sinks were produced, for example, by the Kearsarge (U-19ax), Kernville (U-20ar), Tafi (U-20ae), and Greeley (U-20g) detonations (Plate 1). At Yucca Flat, some collapse sinks contain one or more interior sinks that are thought to be the result of post-detonation collapse of near-surface voids within the chimney (Allen and others, 1997). The Bilby (U-3cn) detonation in Area 3, for example, produced a large, irregular collapse sink having two interior sinks centered at SGZ.

\subsubsection{Cracks:}

Cracks form complex patterns of radial, circumferential, tangential, linear, and randomly oriented surface effects that extend outward from SGZ, and are most prevalent at the margins of collapse sinks (Figs. 3 and 6). At some sites, however, cracking may be subdued or altogether absent, such as at U-20ae. Radial and circumferential cracks are attributed to the rising and falling of the ground surface in response to the passage of the shock wave produced by the explosion. These types of cracks are restricted to the area nearest SGZ and generally occur on prepared surfaces such as drill pads and roadways. At Pahute Mesa, radial cracking on roadways was produced by the Cybar (U-19ar) and Sheepshead (U-19aa) detonations (Covington, 1987) and circumferential cracking was produced around sinks by the Boxcar (U-20i) and Delamar (U-20at) detonations and along roadways by the Alamo (U-19au) and Lockney (U-19aq) detonations. In some cases, cracks associated with sink formation do not extend beyond the actual sink area, as noted at the sites of the Tafi (U-20ae) and Kash (U-20af) detonations (Covington, 1987). Randomly oriented cracks are usually the result of differential block motion along cooling joints in volcanic rock and have been observed nearest SGZ at nearly every site on Pahute Mesa. This type of cracking has also been observed several kilometers away from SGZ for some of the larger detonations, and along canyon rims where they form prominent bands, as at the site of the Serena (U-20an) detonation. Linear cracks commonly occur nearest SGZ, but may also occur several kilometers 
away. These cracks are generally long, continuous cracks (tens of meters long) that form parallel to regional structure, or en-echelon cracks that form normal to the local stress field. Linear cracking is inferred to be a reflection of buried faults or previously unrecognized extensions of known faults (Plate 1).

\subsubsection{Faults:}

Faulting and the reactivation of known faults is the most prominent, linearly extensive, explosion-induced surface feature at Yucca Flat and Pahute Mesa. Numerous detonations throughout these testing areas produced fault movements with vertical displacements in the tens of centimeters over great distances. The largest fault system is the Yucca Fault Zone. It trends north to south through Yucca Flat and is clearly visible on aerial photographs, shaded relief maps (Fig. 2), and surface effects maps (Figs. 3 and 4). At Pahute Mesa, spectacular fault movements were produced by "high yield" experiments during the late 1960's and early 1970's. Fault movements largely occurred at many locations on previously recognized faults, but also occurred on unrecognized (or buried) faults. West of the Kearsarge (U-19ax) detonation and at the site of the Tybo (U-20y) detonation (Maldonado, 1977), movements occurred on previously unrecognized faults. Extensions of known faults occurred at many sites, for example, southeast of U-19L and southwest of U-20aa (Snyder, 1971; Maldonado, 1977). The longest, single-feature fault movement mapped at either testing area occurs as part of the Boxcar Fault located east of the site of the Colby (U-20aa) detonations (Plate 1).

\subsubsection{Pressure Ridges:}

Pressure ridges are expressed as sinuous mounds of earth that are rarely more than a kilometer away from SGZ. These sinuous mounds are the result of differential motion in the near-surface materials as the shock wave produced by the detonation expands outward from SGZ. In some cases, the sinuous mounds are simply soil pushed into piles from the passage of the shock wave. This occurred north of the Tenabo (U-20bb) detonation and northwest of the Colwick (U-20ac) detonation (Covington, 1987). In extreme cases, slabs of rock override each other and "bulldoze" rock and soil as they move. This occurred north of the Fontina (U-20f) detonation (Maldonado, 1977) and at the Hornitos (U-20bc) detonation at Pahute Mesa (Plate 1).

\subsection{GIS Digital Map Data}

Plate 1 offers a comprehensive look at the combined surface effects of underground nuclear tests conducted at Pahute Mesa from 1965 to 1992. A similar map for Yucca Flat (Grasso, 2000; Plate 1) shows the combined surface effects of 530 of the 747 detonations conducted at Yucca Flat from 1951 to 1992 . While these maps clearly illustrate the surface effects produced by nuclear testing, they do not show the true analytical power of the GIS surface effects map archive. The archive combines the benefits of easy data access and map retrieval and display, with the capabilities to scientifically analyze these data in combination with other related site and environmental information. For example, the GIS archive can be easily queried; surface effects maps can be retrieved and printed; and various attribute information can be prepared in tabular format (for example, Table 2) or combined with other chronological, geographical, geological, and hydrological maps and databases. 
The large-scale composite GIS map of Pahute Mesa (Plate 1) is an example of a basic map retrieval and printing operation. In this case, all surface effects maps and sites data for Pahute Mesa were retrieved and placed on prepared basemap layers of the NTS; the latter also contained in the surface effects map archive. Thus, the combined surface effects of all 85 underground nuclear detonations at Pahute Mesa are shown. Similarly, maps of the surface effects produced by a single detonation (Fig. 3) or a group of detonations (Fig. 4) can be quickly prepared. For more advanced analysis, however, the detonation sites database (Table 4) can be used in conjunction with these surface effects map data. This approach permits the user to perform more complex data retrieval and mapping tasks based on detonation and borehole characteristics. For examples, the surface effects of all detonations conducted during a particular time; occurring within a particular area; having a specific magnitude range; or caused by tests conducted within an explicit DOB range can be retrieved and mapped. In addition, these data can be linked to other external databases for more complex data retrieval, analysis, and mapping operations.

\subsection{Content and Structure of the Archive on CD-ROM}

The GIS surface effects map archive on CD-ROM contains surface effects maps for the Yucca Flat and Pahute Mesa testing areas and basemaps for the NTS. The GIS maps are shape files (themes) that were prepared using Arcview GIS (v. 3.2a) from Environmental Systems Research Institute, Inc. These maps can be used by any GIS software application that is capable of reading (or importing) Arcview shapefiles.

The GIS maps are arranged by data type, area of coverage, and map coordinate system. A logical collection of folder names and filenames reflect this data structure. Principal data types include: (1) basemaps, (2) surface effects maps, and (3) the detonation (borehole) sites database. Areas of coverage include: (1) NTS, (2) Yucca Flat and Pahute Mesa testing areas, (3) NTS Operational Areas, and (4) individual detonation sites. All of the GIS maps are in Nevada State Plane (NSP, Central, NAD27, in feet) coordinate system, unless otherwise noted. Surface effects maps are also provided in three commonly used map coordinate systems-Geographic (NAD27), Geographic (NAD83), and Universal Transverse Mercator (UTM) Zone 11 (NAD83)—to improve compatibility with other externally available digital maps and databases.

The following sections describe these data, their content, and organization in the archive. Table 2 gives summary statistics for mapped surface effects at Yucca Flat and Pahute Mesa. Tables 3 and 4 list attribute fields for the GIS surface effects maps and detonation sites database, and provide descriptions of content, example data, and data types. Table 5 lists the organizational structure of these data on CD-ROM by testing area. A representative sample of files is listed to illustrate the content and structure of the archive. Folder names, filenames, descriptions of content, metadata filenames, and data types are given.

Standard Federal Geographic Data Committee (FGDC) metadata files, containing detailed descriptions of the GIS surface effects maps, are included in the archive for the Yucca Flat and Pahute Mesa testing areas. The metadata files are named yfse_metadata.met and pmse_metadata.met. Hyper-text-markup-language (HTML) file area also included. Metadata are also provided for NTS basemap themes. 


\subsubsection{Surface Effects Maps:}

GIS surface effects maps for Yucca Flat and Pahute Mesa are arranged within folders named "yfse" and "pmse." Within these folders, surface effects map are provided in four map coordinate systems for (1) the testing area, (2) NTS Operational Areas (e.g., Area02; Area03; etc.), and (3) individual detonation (borehole) sites (e.g., U-2dg; U-4d; etc.). Subfolders contain these data subclasses. Table 5 lists and describes a representative sample of these GIS surface effects maps as they are organized within the archive.

\subsubsection{Detonation (Borehole) Sites Database:}

The GIS surface effects map archive contains a database of detonations and boreholes. The sites database theme (se_sites_n27f.shp) has an entry (record) for each detonation conducted at the NTS and contains information about the detonation, borehole, and surface effects map. The primary purpose of this database is for locating, tracking, and mapping relevant detonation, borehole, and surface effects map information, and for performing data analysis and retrieval tasks. The database is a GIS point theme containing location and attribute information for each detonation. Where more than one detonation was conducted within a single borehole, multiple borehole entries are listed in the field "Siteid." The detonation names listed in the field "Name" are unique, thus, each record in the database pertains to a single detonation. Table 4 lists and describes the fields and content of the database. The sites database theme is provided in each of the four map coordinates-Nevada State Plane (NAD27), Geographic (NAD27), Geographic (NAD83), and Universal Transverse Mercator (UTM) Zone 11 (NAD83)—discussed above. The respective coordinate systems are indicated by the last four alphanumerical characters of their file names, $n 27 f, g 27 d, g 83 d$, and $u 83 m$. Field entries for these coordinates systems are also provided.

\subsubsection{Basemaps:}

Relevant GIS basemaps of the NTS, Nevada, and the Western United States are included in the archive (Table 5). These maps are useful for viewing and printing surface effects maps and for general information about the testing areas. Most of these maps were provided by the Yucca Mountain Project Office (Yucca Mountain Project, 1998, GIS CD-ROM). Minor modifications made included filename changes, clipping to the NTS boundary, and some changes to field names and attributes. Moreover, some of the primary and secondary roads and trails show on the roads theme (nts_roads.shp) were updated to correspond to the locations of these features on 1:24,000-scale USGS Digital Line Graph maps for the Yucca Flat area.

\subsubsection{Original Surface Effects Maps:}

Many of the original surface effects maps are also included in the archive as georeferenced, raster-based, digital reproductions. Many hours went into the production of these maps as an intermediate step in transforming the original analog-based maps to GIS vector-based formats. These original surface effects maps are organized in folders by testing area, NTS Operational Area, and borehole (Siteid) name (Table 5). Most of these maps are the original surface effects maps of individual detonation sites. Some are composite maps showing the combined surface effects of multiple detonation sites. In addition, three large-scale composite surface effects maps ("crack maps") of Yucca Flat were also scanned and georeferenced. The georeferenced, raster- 
based reproductions of these crack maps, which cover all of Yucca Flat, are also included in the archive as four separate files. Table 5 describes these files for Yucca Flat.

\subsection{View the Maps and Explore the Databases on CD-ROM}

The GIS surface effects map archive contains ArcExplorer (v. 2), a GIS map and database viewer for Microsoft Windows. This program can be used to view and explore the surface effects maps, databases, and basemaps contained in the archive. ArcExplorer project files are included on CD-ROM for easy access to these GIS maps and databases.

ArcExplorer (AE) is provided by Environmental Systems Research Institute, Inc. This software can be freely distributed with GIS data sets, such as the surface effects map archive. The program is invaluable for viewing GIS maps and exploring databases. To view the surface effects maps you must first install ArcExplorer on your computer.

\subsubsection{Install ArcExplorer:}

Navigate to the folder named “..AArcExplorerVnstalN” on CD-ROM and run the ae2setup.exe program. Follow the on-screen instructions. When complete, a new ArcExplorer icon will appear on the Window's desktop. Double click the icon to start the program.

\subsubsection{View the Surface Effects Maps:}

From within ArcExplorer, open one of the prepared project files in the root folder on CD-ROM. The files yfse.aep and pmse.aep display all of the surface effects maps for the Yucca Flat and Pahute Mesa testing areas. These maps are similar to the large-scale maps prepared for Yucca Flat (Grasso, 2000; Plate 1) and Pahute Mesa (Plate 1, this report). The file basemaps.aep displays the basemap themes provided for the NTS. The file semaps.aep displays the surface effects maps of both Yucca Flat and Pahute Mesa on a shaded relief basemap of the NTS. This is the most comprehensive of the prepared ArcExplorer project files. Other example maps include three individual surface effects maps for detonations conducted at U-7y, U-10k, and U-20y (u-7y.aep, u-10k.aep, and u-20y.aep) in the Yucca Flat and Pahute Mesa areas.

As you explore the prepared maps, note that many of the map layers are set to turn on and off at specific map (view) scales. As you zoom in to enlarge the map scale, more map data is revealed as the individual map layers are displayed. For example, the bar-and-ball symbol themes, which show measured offset on faults, are the last to be displayed when zooming in on the maps. This occurs because the maps are set to display when the view scale is larger than about 1:18,000.

Use the prepared ArcExplorer maps to explore the surface effects archive, and as templates for constructing additional maps. Many combinations of maps can be prepared by loading any of the area-wide or site-specific surface effects maps from the archive. Note, however, that you will have to uniquely categorize and color the lines and symbols for each theme that you add to the AE project file. Simply use the prepared maps as a guide. This is a limitation of AE. When you load any of the surface effects maps into Arcview the line weights, styles, and colors for the mapped features will be automatically set. Arcview uses legend (*.avl) files to set these map 
parameters. All of the GIS themes contained in the archive contain legend files. The legend files have the same name as the theme and the avl three-letter file extension.

\subsubsection{Explore the Databases:}

The AE project files contain the detonation sites database that shows the locations of all detonation sites at the NTS. The sites are displayed as uniquely colored points on the maps, similar to that shown on Figure 1. Site categories are based on the database attribute status, which identifies whether a surface effects map was prepared for the detonation (Table 4). Detonation tables are also provided in folder “..Wocuments Detonations $\$ ” on CD-ROM. These tables contain a partial list of attributes contained in the database and are useful for quickly determining whether a surface effects map was prepared and what types of surface effects were mapped. The tables are sorted by detonation date, name, and siteid as indicated by their filenames. Use your web browser or Adobe Acrobat Reader to view the respective " $h t m l$ " or " $p d f$ " files.

From within ArcExplorer, use the identify or query tools to quickly retrieve and view the attribute data for any detonation contained in the sites database. Select the identify tool and simply point to and click on the site symbol shown on the prepared maps. A complete list of attributes contained in the database is displayed. Use the query tool to select groups of sites based on a user-defined query expression. The query searches the database and returns a selected group of sites based on the results of the query. Field descriptions for the information retrieved for the site (using the identify tool) or group of sites (using the query tool) are listed in Table 4 and in the metadata file for the theme. These procedures can also be used to retrieve attribute information for any surface effects feature or group of features displayed on the maps. Simply point and click on the feature or query the surface effects map's attribute table. Field descriptions for the information retrieved are listed in Table 3 and in the metadata file for these themes.

ArcExplorer provides many other useful tools for viewing and retrieving map data. For example, you can zoom and pan the displayed map; query, select, and display groups of surface effects or detonation sites; and print the maps. For more information on how to use ArcExplorer and its many map and database tools, please see the 81-page users manual or the 38-page slideshow on CD-ROM. The locations of these materials are listed below. Note that these documents are in Adobe Acrobat format. You will need to have Adobe Acrobat Reader installed on your computer to view these materials. A copy of Acrobat Reader for Microsoft Windows is included.

The software programs and documentation discussed above can be found in the following locations on CD-ROM (this report). These materials are current as of August 15, 2001 and can be freely distributed. Newer versions may be available on the World Wide Web.

- Install ArcExplorer

- Install Adobe Acrobat Reader

- View ArcExplorer Manual

- View ArcExplorer Slideshow
(..ArcExplorer\nstallae2setup.exe)

(..AAcrobat Install $\backslash a r 500$ enu.exe or ar405eng.exe)

(..AArcExplorer\Manual\AE_Manual.pdf)

(..AArcExplorerlSlideshow $\left.\backslash A E \_S l i d e s h o w . p d f\right)$ 


\section{SECTION 4}

\subsection{References}

Allen, B.M., Drellack, S.L., Jr., Townsend, M.J., 1997, Surface Effects of Underground Nuclear Explosions: U.S. Department of Energy Report DOE/NV/11718-122, 147 p.

Carothers, J.E., 1995, Caging the Dragon-The containment of underground explosions: U.S. Department of Energy Report DOE/NV-388, 726 p.

Covington, H.R., 1987, Map showing surface features induced by underground nuclear explosions at Pahute Mesa, Nevada Test Site, Nye County, Nevada, April 1976 through December 1983: U.S. Geological Survey Miscellaneous Investigations Series Map I1872, scale 1:48,000.

Drellack, S.L., Jr., 1988, Fenix and Scisson Field Mapping Procedures: Fenix and Scisson Memo GEO-0451.

Garcia, M.N., 1997, Field and Photogrammetric Methods for Mapping Nuclear Induced Surface Effects at the Nevada Test Site, Nye County, Nevada: U.S. Geological Survey Open-File Report 97-695, 18 p. (Included on CD-ROM is an Adobe Acrobat copy of this report. It is located in folder “...Documents $\backslash$ OFR97-695】”)

Grasso, D.N., 2000, Geologic Surface Effects of Underground Nuclear Testing, Yucca Flat, Nevada Test Site, Nevada: U.S. Geological Survey Open-File Report 00-176, 20 p., 7 figs., 1 table, 1 map plate. (Included on CD-ROM are Adobe Acrobat copies of this report and map plate. They are located in folder “..Wocuments $\backslash$ OFRO0-170”)

Houser, F.N., 1970, A summary of information and ideas regarding sinks and collapse, Nevada Test Site: U.S. Geological Survey report USGS-474-41, 30 p.

Maldonado, Florian, 1977, Composite post-shot fracture map of Pahute Mesa, Nevada Test Site, June 1973 through March 1976: U.S. Geological Survey Report USGS-474-243, 8 p., 1 plate; available only from U.S. Department of Commerce, National Technical Information Service, Springfield, VA 22161.

McKeown, F.A. and Dickey, D.D., 1967, Maps of explosion-produced fractures in Yucca Valley, Nevada Test Site: U.S. Geological Survey Technical Letter: NTS-195, 4 p.

U.S. Department of Energy, 1994, United States Nuclear Tests, July 1945 through September 1992, DOE/NV-209, Revision 14.; Available only from U.S. Department of Commerce, National Technical Information Service, Springfield, Virginia, 22161.

Snyder, R.P., 1971, Composite post-shot fracture map of Pahute Mesa, Nevada Test Site: U.S. Geological Survey Report USGS-474-100, 13 p., 1 plate; available only from U.S. Department of Commerce, National Technical Information Service, Springfield, VA 22161.

Terry, Herman, 1990, RSN Drilling and Mining Summary (Red Book), map. 


\subsection{Figures}

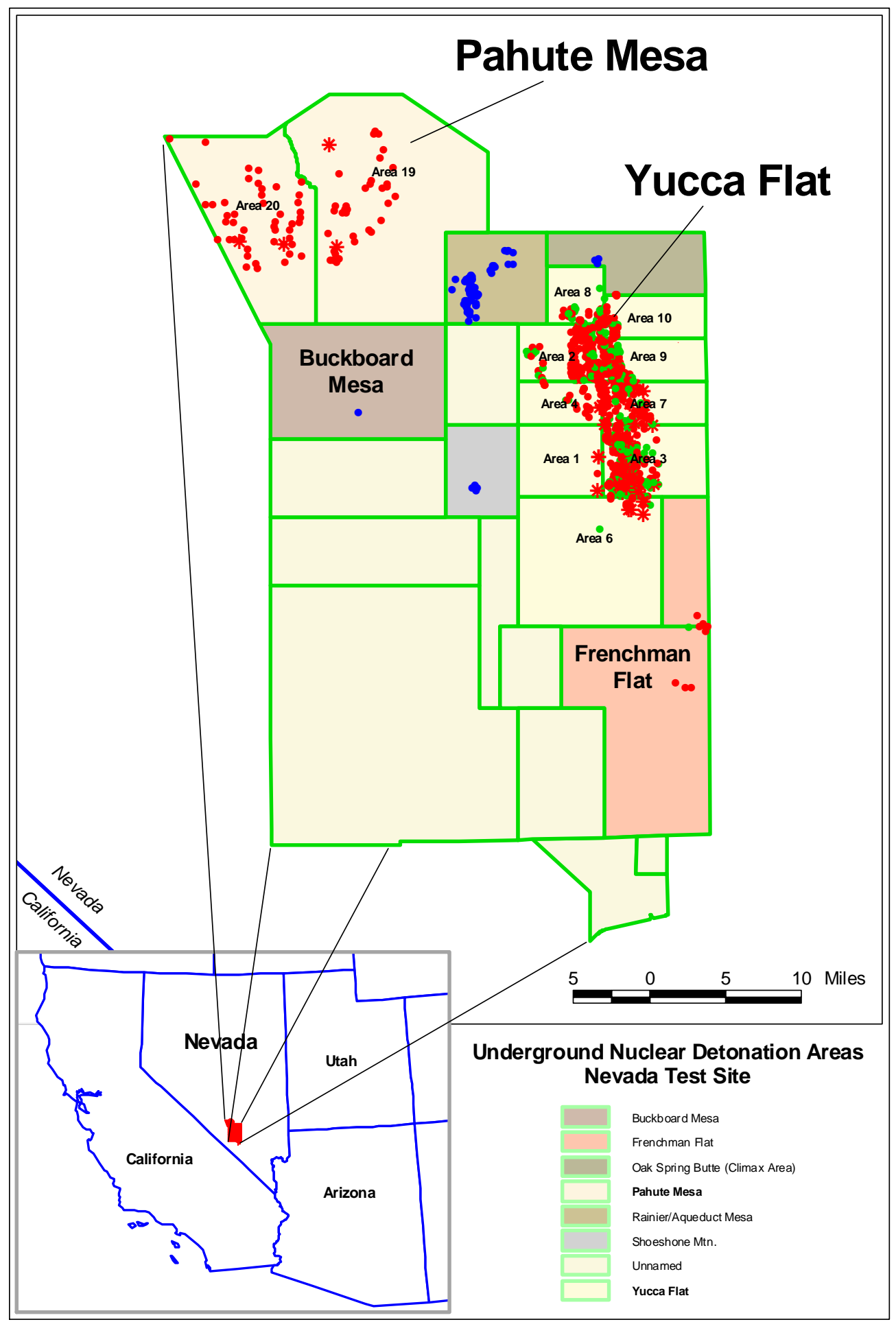

Figure 1-Location map of detonation sites and mapped surface effects, Nevada Test Site, Nevada. Pahute Mesa, Yucca Flat, and Frenchman Flat areas: red dots and red stars indicate sites mapped for surface effects; green dots indicate sites not mapped for surface effects. Other areas: blue dots indicate detonation sites utilized. 


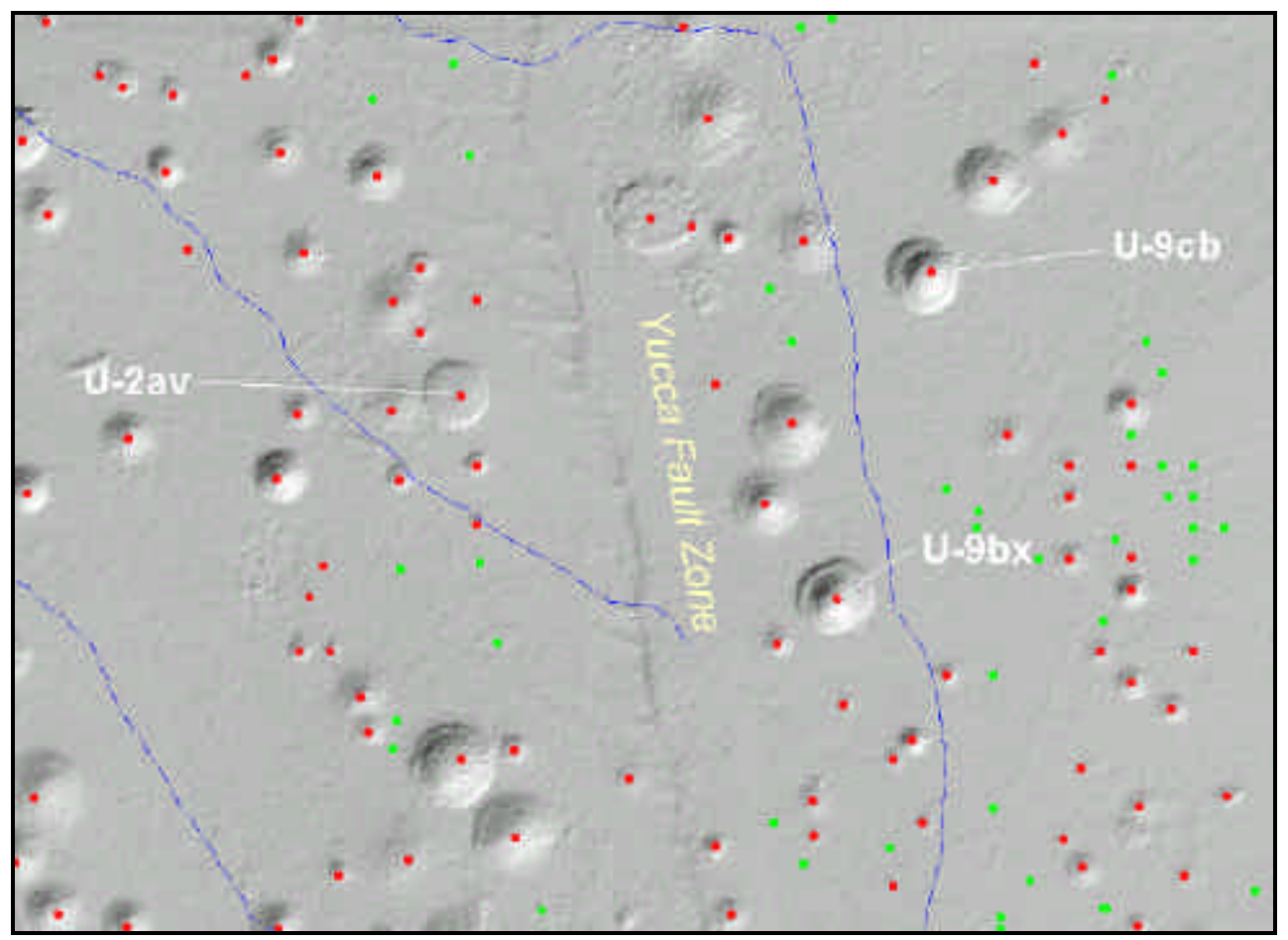

(A)

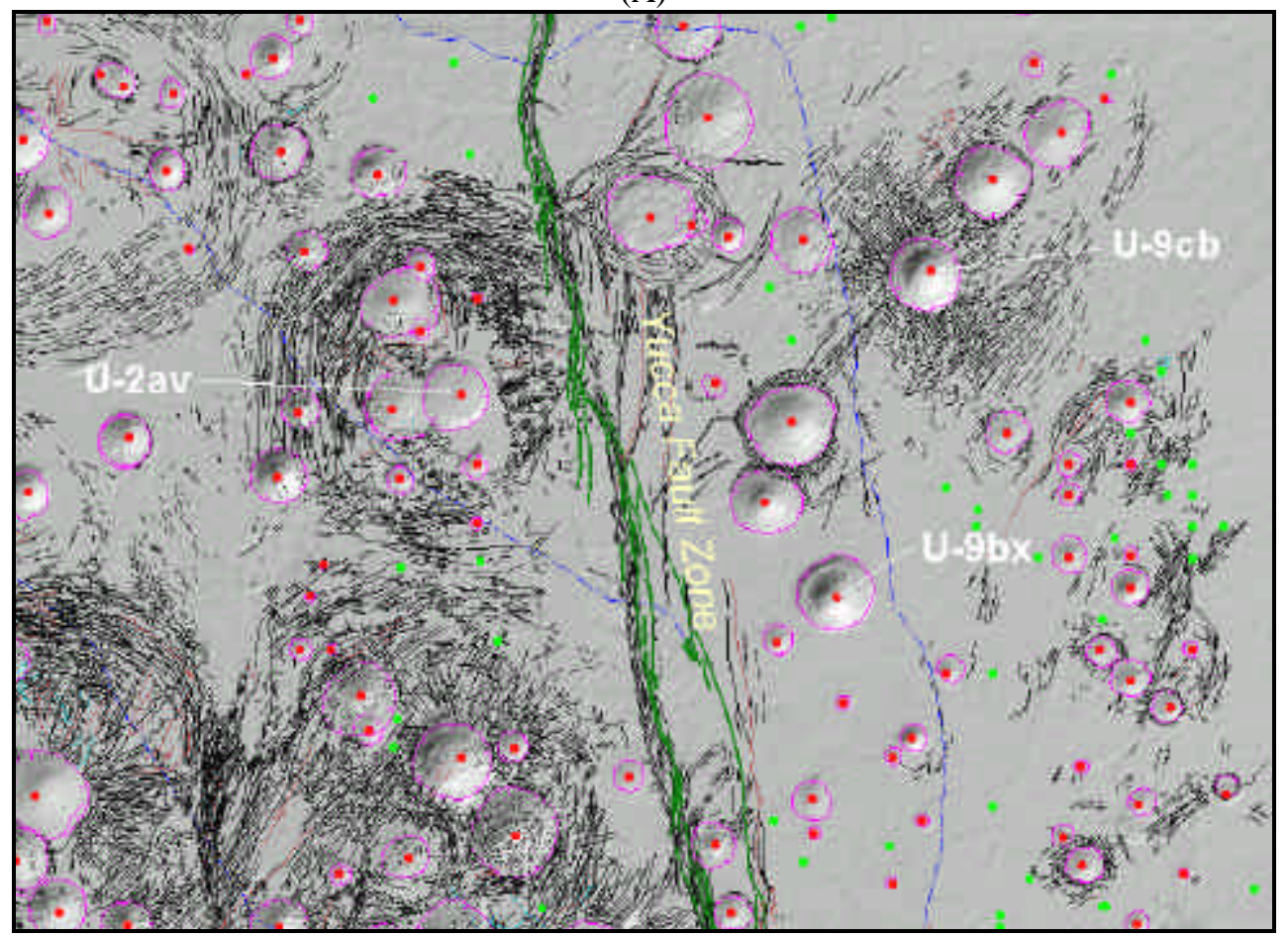

(B)

Figure 2-Shaded relief maps of north-central Yucca Flat, Nevada. Frame (A) shows the topographic effects of underground nuclear testing, ephemeral streams, and the locations of detonation sites. Frame (B) includes mapped surface effects for the same area. Collapse sinks and the north-south trending Yucca Fault Zone are noteworthy features. Symbols and colors depicting GIS surface effects (B) are: Sink (magenta), crack (black), fault (brown), pressure ridge (turquoise), and Yucca Fault (green). Red and green dots indicate sites mapped and not mapped for surface effects. 


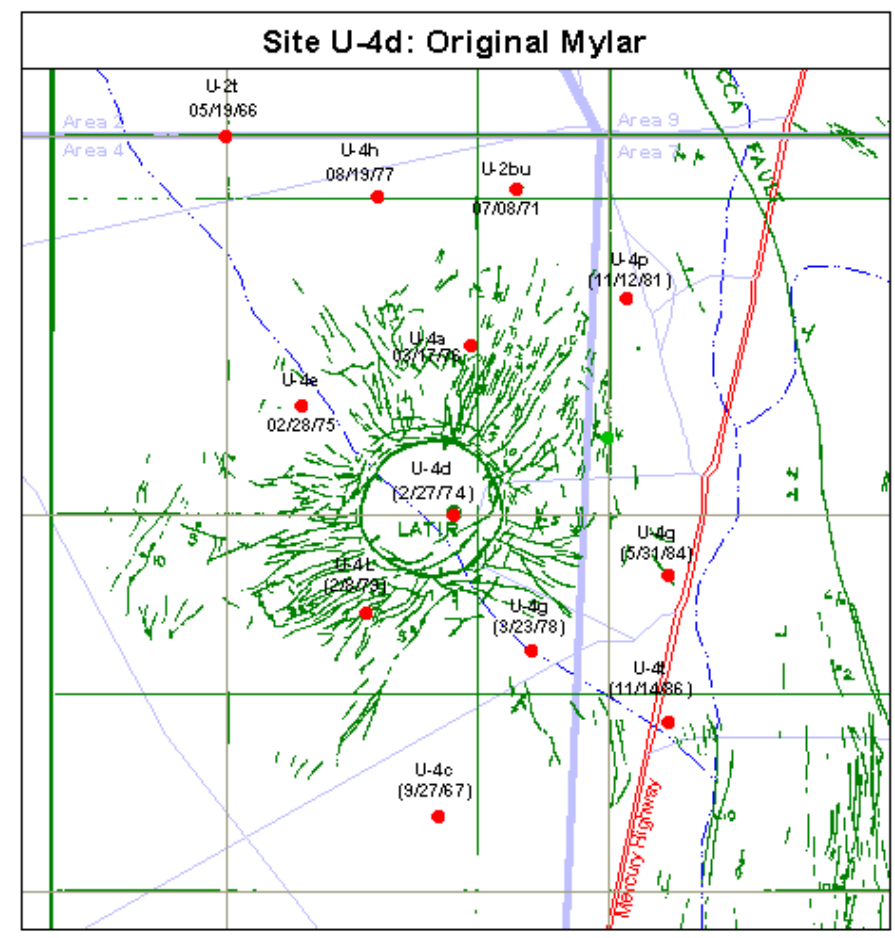

(A)

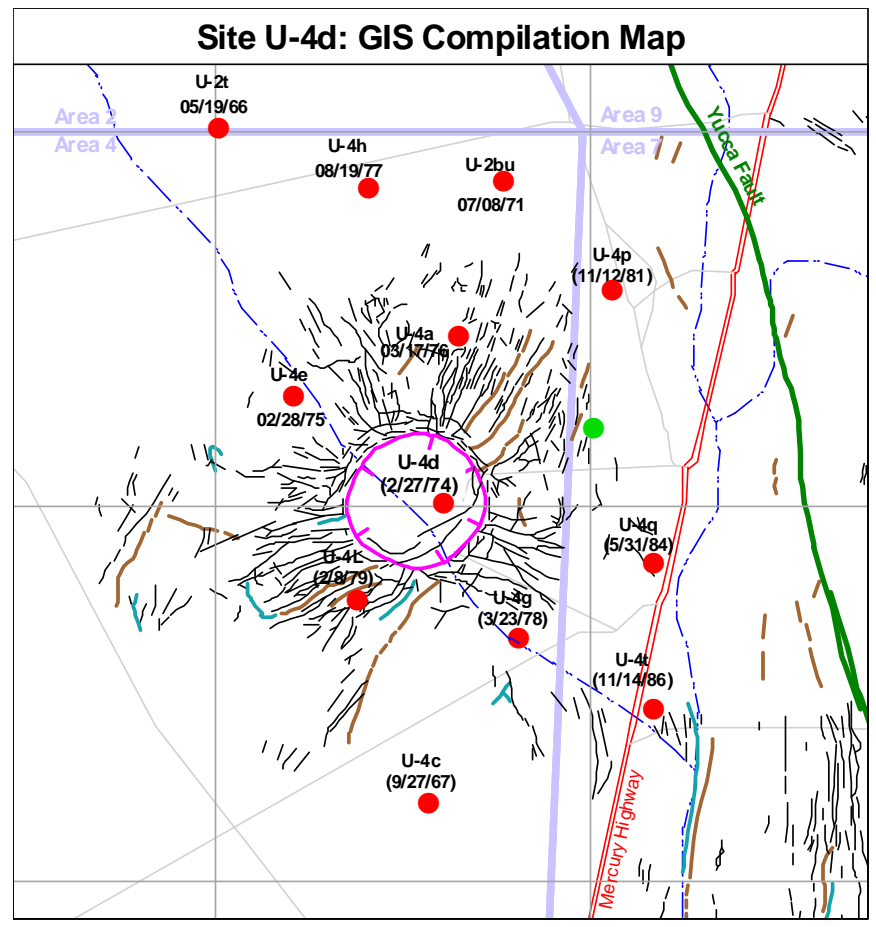

(B)

Figure 3-Surface effects caused by the Latir (U-4d) detonation, Yucca Flat, Nevada. The original hand-drawn "mylar" map (A) is compared to the new GIS digital map (B) for the site. Red and green dots (A; B) indicate sites mapped and not mapped for surface effects. Symbols and colors depicting GIS surface effects (B) are: Sink (magenta), crack (black), fault (brown), pressure ridge (turquoise), and Yucca Fault (green). 


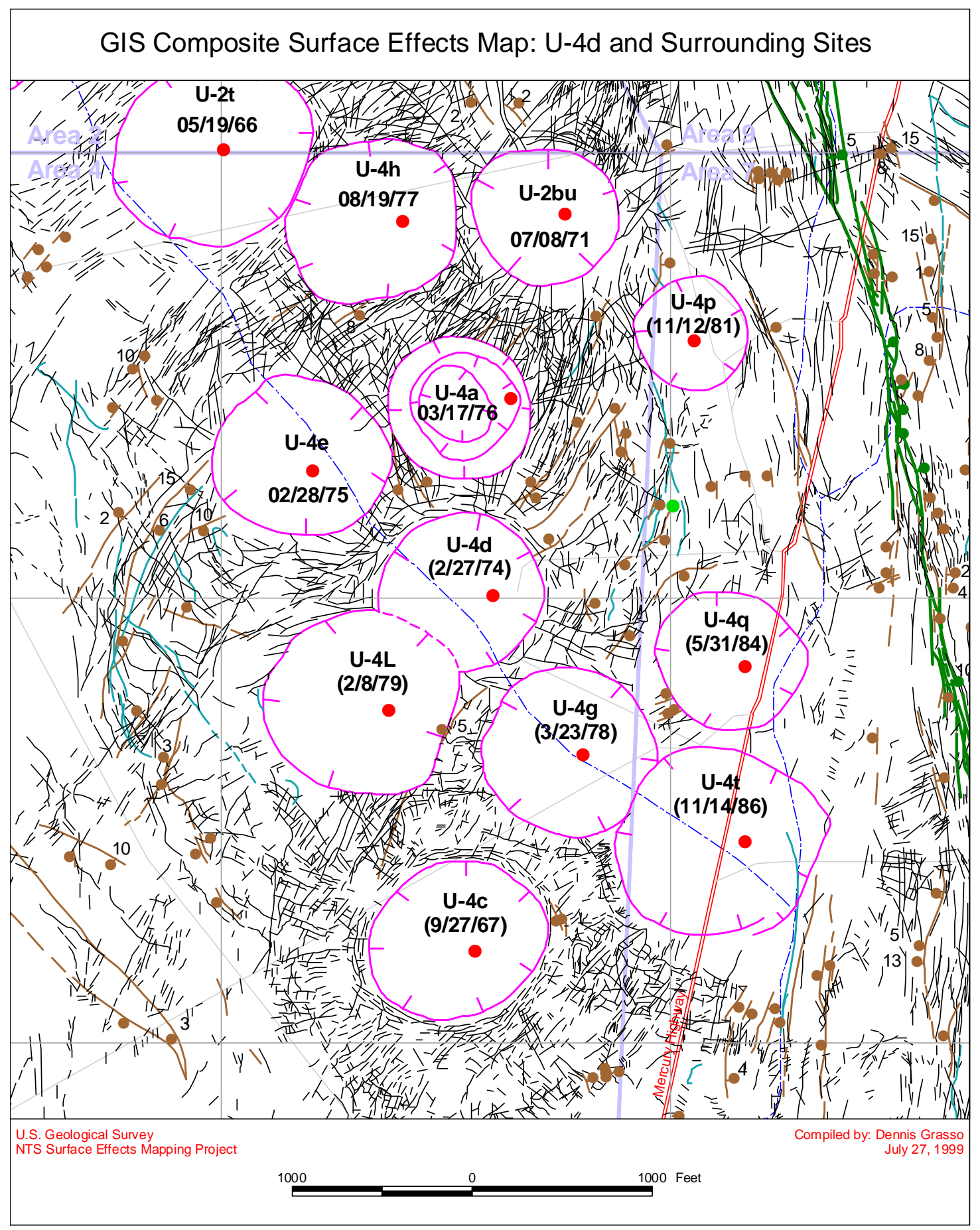

Figure 4-GIS composite surface effects map of Latir (U-4d) and surrounding detonation sites, Yucca Flat, Nevada. Red and green dots indicate sites mapped and not mapped for surface effects. Symbols and colors depicting mapped surface effects are: Sink (magenta), crack (black), fault (brown), pressure ridge (turquoise), and Yucca Fault (green). 


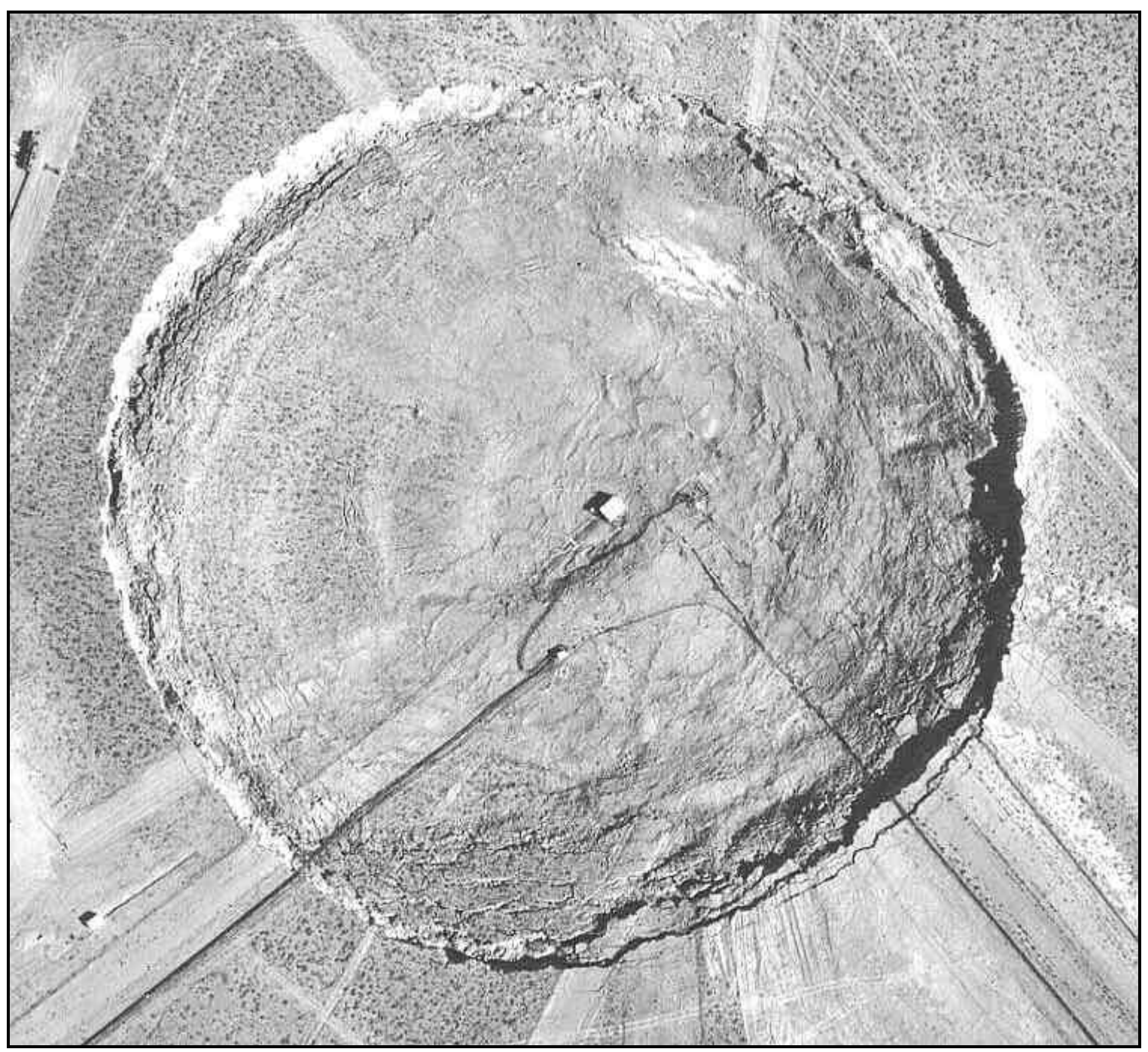

Figure 5-Aerial photograph of collapse sink at Portmanteau (U-2ax) detonation site, Yucca Flat, Nevada. Portmanteau was detonated on August 30, 1974. This photograph was taken seven days later on September 6, 1974. Note the distinctive edge of the collapse sink and presence of surface materials that subsequently slumped into the sink at its perimeter. 


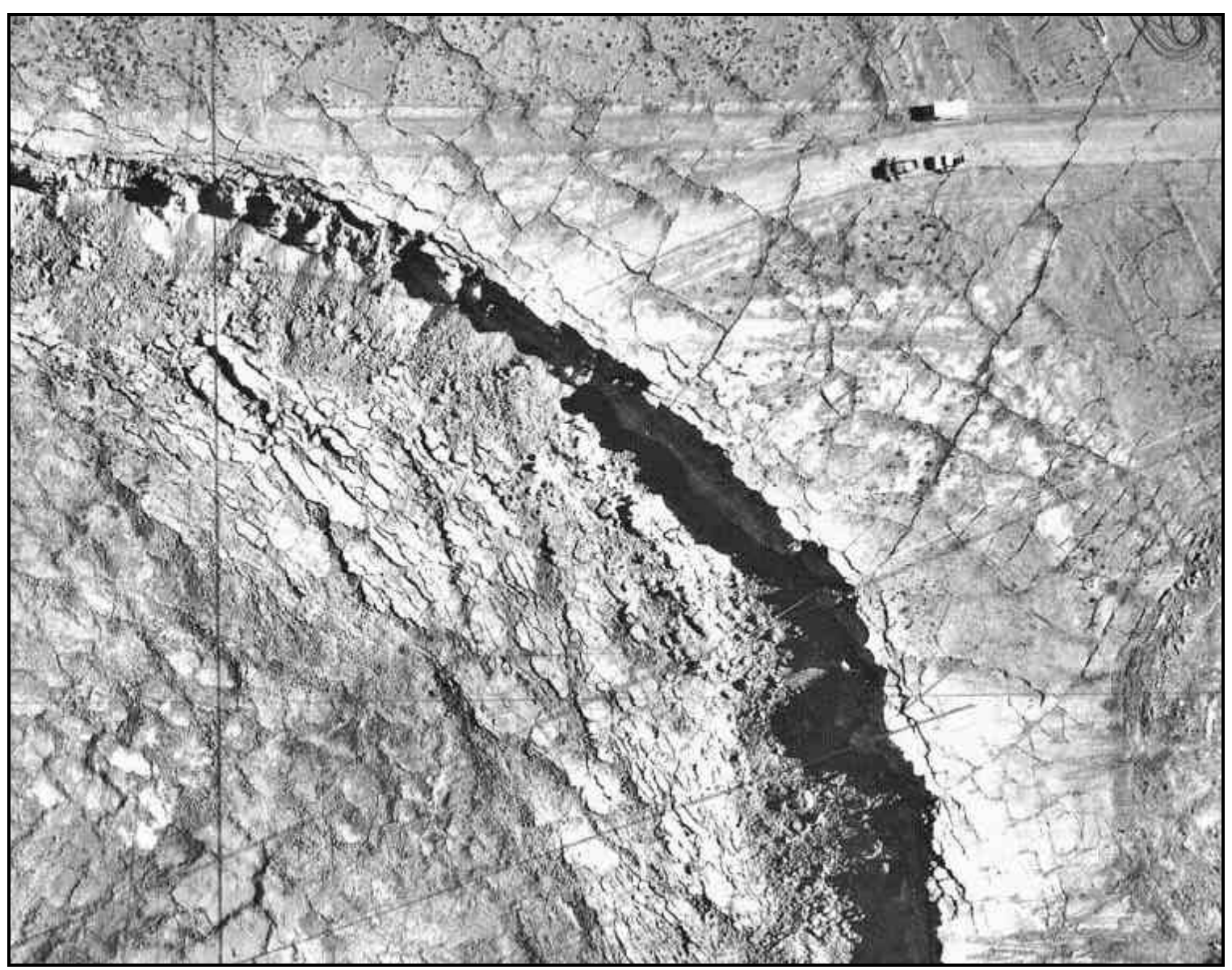

Figure 6-Aerial photograph of collapse sink at Commodore (U-2am) detonation site, Yucca Flat, Nevada. Commodore was detonated on May 20, 1967. The distinct edge of the sink and the occurrence of radial and concentric cracks extending from its perimeter are prominent surface effects at this site. Note the two trucks on the "truncated" dirt road at upper right. 


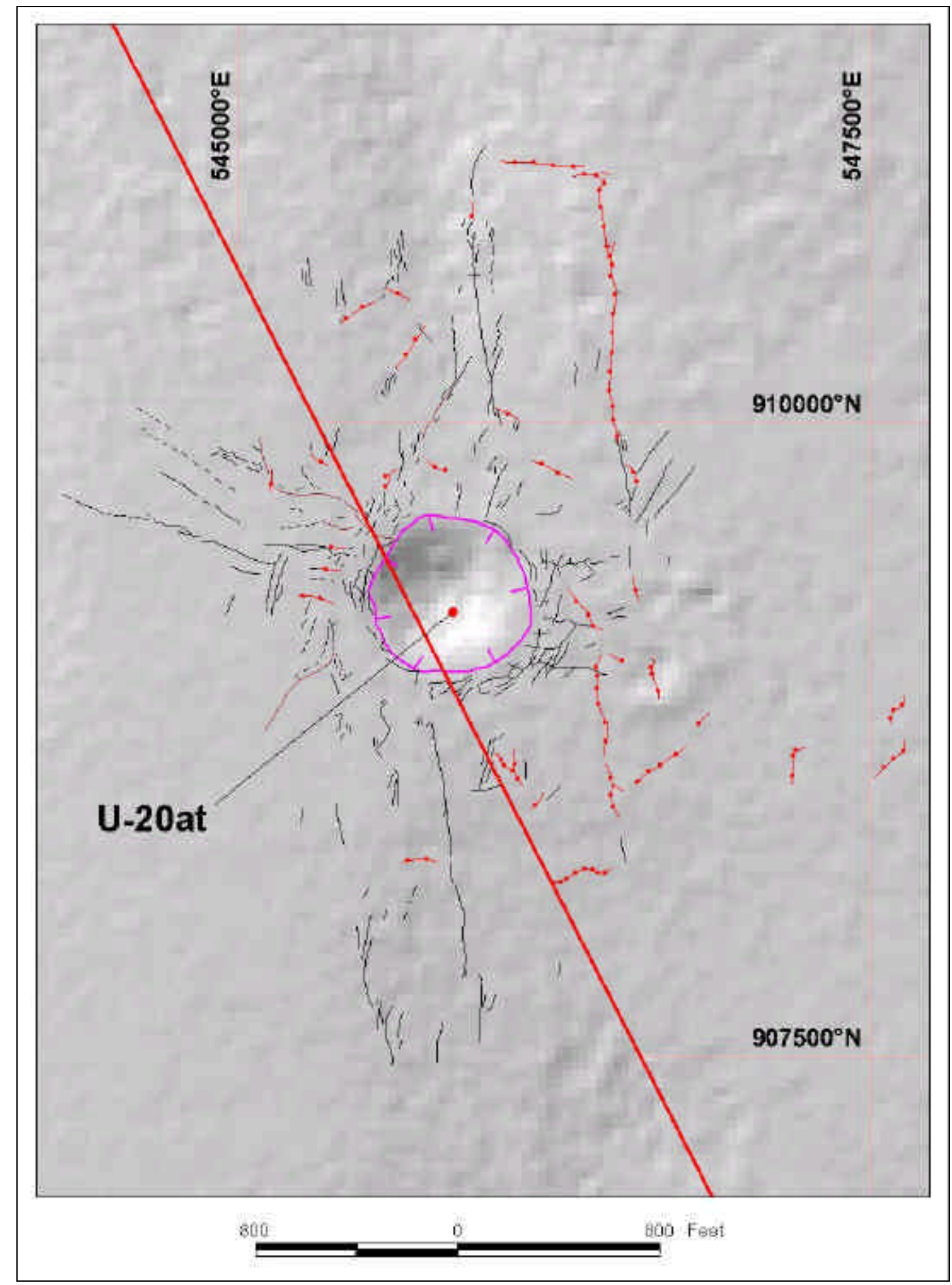

Figure 7-GIS surface effects map of Delamar (U-20at) detonation site, Pahute Mesa, Nevada. Mapped, GIS surface effects of U-20at are shown as an overlay on a shaded relief basemap for the detonation site. Symbols and colors depicting mapped surface effects are: Sink (magenta), crack (black), fault (brown), and pressure ridge (red with red balls). The southwestern border of Area 20 is shown as a heavy red line that bisects the site from northwest to southeast. 


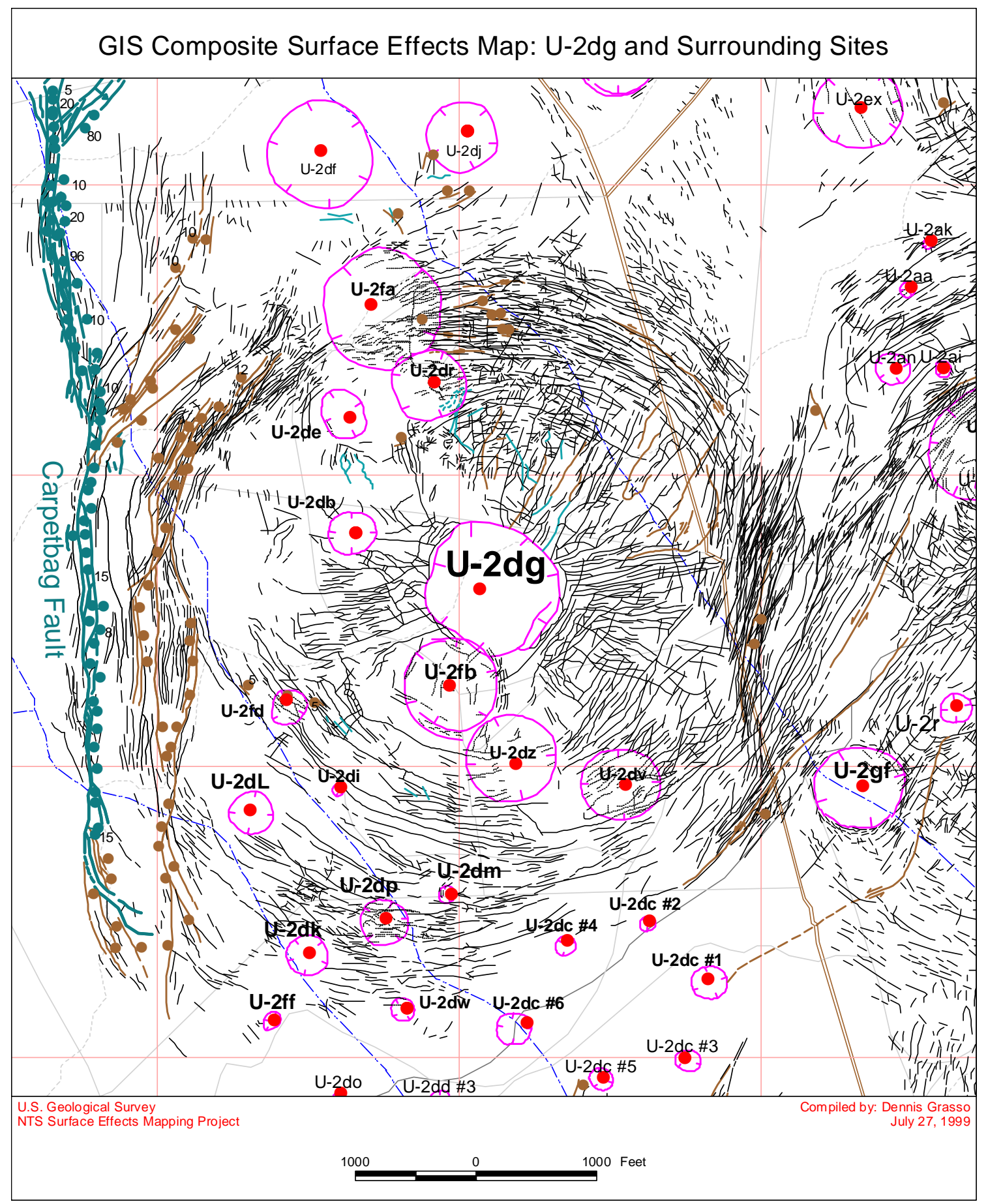

Figure 8-GIS composite surface effects map of Carpetbag (U-2dg) and surrounding detonation sites, Yucca Flat, Nevada. Red dots indicate sites mapped for surface effects. Symbols and colors depicting mapped surface effects are: Sink (magenta), crack (black), fault (brown), pressure ridge (turquoise), and Carpetbag Fault (blue-green). 


\subsection{Tables}

Table 1-Number of detonations, boreholes, and surface effects maps for underground nuclear tests conducted within the Yucca Flat and Pahute Mesa Testing Areas, Nevada Test Site, Nevada

[Note: Number of detonations and boreholes are based on borehole identification number (Siteid), not on their locations within the present-day boundaries of NTS Operational Areas. Of the 832 detonations conducted at Yucca Flat and Pahute Mesa, six were crater detonations-three at Area 10 (Uncle, Ess, and Sedan), Yucca Flat, and three at Area 20 (Palanquin, Cabriolet, and Schooner), Pahute Mesa. Additionally, one non-nuclear, HE-TNT crater test (Scooter) was conducted in Area 10. Information about this non-nuclear detonation is included in the sites database theme (se_sites_n27f.shp), and a surface effects map is included in the archive, but this site is not include here because it was a non-nuclear test.]

\begin{tabular}{|c|c|c|c|c|c|}
\hline \multirow{2}{*}{$\begin{array}{c}\text { NTS } \\
\text { Operational } \\
\text { Area }\end{array}$} & \multicolumn{2}{|c|}{ Underground Nuclear Tests } & \multicolumn{3}{|c|}{ Surface Effects Maps } \\
\hline & $\begin{array}{l}\text { Number of } \\
\text { Detonations }\end{array}$ & $\begin{array}{l}\text { Number of } \\
\text { Boreholes }\end{array}$ & $\begin{array}{c}\text { Detonations } \\
\text { Mapped }\end{array}$ & $\begin{array}{c}\text { Boreholes } \\
\text { Mapped }\end{array}$ & $\begin{array}{l}\text { Detonations } \\
\text { Not Mapped }\end{array}$ \\
\hline \multicolumn{6}{|c|}{ Yucca Flat } \\
\hline Area 1 & 4 & 3 & 4 & 3 & 0 \\
\hline Area 2 & 162 & 153 & 133 & 125 & 29 \\
\hline Area 3 & 274 & 272 & 178 & 177 & 96 \\
\hline Area 4 & 39 & 35 & 37 & 33 & 2 \\
\hline Area 6 & 6 & 6 & 5 & 5 & 1 \\
\hline Area 7 & 62 & 62 & 53 & 53 & 9 \\
\hline Area 8 & 12 & 10 & 5 & 5 & 7 \\
\hline Area 9 & 118 & 114 & 70 & 70 & 48 \\
\hline Area 10 & $\underline{70}$ & $\underline{64}$ & $\underline{45}$ & $\underline{45}$ & $\underline{25}$ \\
\hline Subtotal & 747 & 719 & 530 & 516 & 217 \\
\hline \multicolumn{6}{|c|}{ Pahute Mesa } \\
\hline Area 19 & 36 & 36 & 36 & 36 & 0 \\
\hline Area 20 & $\underline{49}$ & $\underline{48}$ & $\underline{49}$ & $\underline{48}$ & $\underline{0}$ \\
\hline Subtotal & 85 & 84 & 85 & 84 & 0 \\
\hline Total & 832 & 803 & 615 & 600 & 217 \\
\hline
\end{tabular}


Table 2-Surface effects summary statistics for the Yucca Flat and Pahute Mesa Testing Areas

[Notes: Listed for each feature type are the number of features, maximum length, and cumulative length. Maximum length is the length of the longest feature. Cumulative length is the combined length of a feature for all surface effects maps within the Yucca Flat or Pahute Mesa testing areas. Feature types listed are those contained in the attribute field Feature of the GIS surface effects maps. Feature types marked by asterisks $(*)$ are unique to Yucca Flat.]

\begin{tabular}{|c|c|c|c|c|c|}
\hline \multirow[t]{2}{*}{ Feature Type } & \multirow{2}{*}{$\begin{array}{c}\begin{array}{c}\text { Number } \\
\text { of } \\
\text { Features }\end{array} \\
\end{array}$} & \multicolumn{2}{|c|}{ Maximum Length } & \multicolumn{2}{|c|}{ Cumulative Length } \\
\hline & & $($ feet $)$ & (meters) & $($ feet $)$ & (meters) \\
\hline \multicolumn{6}{|c|}{ Yucca Flat Surface Effects } \\
\hline Crack & 47,522 & 2,509 & 765 & $5,797,406$ & $1,767,049$ \\
\hline Crack within sink & 3,132 & 1,150 & 350 & 396,434 & 120,833 \\
\hline Fault & 1,283 & 7,378 & 2,249 & 384,426 & 117,173 \\
\hline Fault within sink & 125 & 1,526 & 465 & 34,136 & 10,405 \\
\hline Pressure Ridge & 183 & 1,640 & 500 & 51,053 & 15,561 \\
\hline Pressure Ridge within sink & 20 & 719 & 219 & 3,883 & 1,184 \\
\hline Sink & 2,957 & 4,379 & 1,335 & 887,254 & 270,435 \\
\hline Sink within sink * & 32 & 673 & 205 & 7,458 & 2,273 \\
\hline Carpetbag Fault * & 189 & 5,514 & 1,681 & 66,469 & 20,260 \\
\hline Yucca Fault* & $\underline{458}$ & 7,837 & $\underline{2,389}$ & $\underline{235,894}$ & 71,901 \\
\hline Summary & 55,901 & & & $7,864,414$ & $2,397,073$ \\
\hline \multicolumn{6}{|c|}{ Pahute Mesa Surface Effects } \\
\hline Crack & 15,390 & 6,745 & 2,056 & $2,137,573$ & 651,532 \\
\hline Crack within sink & 230 & 536 & 163 & 16,951 & 5,167 \\
\hline Fault & 718 & 15,865 & 4,836 & 678,773 & 206,890 \\
\hline Fault within sink & 3 & 277 & 84 & 475 & 145 \\
\hline Pressure Ridge & 334 & 3,319 & 1,012 & 120,994 & 36,879 \\
\hline Pressure Ridge within sink & 1 & 465 & 142 & 465 & 142 \\
\hline Sink & $\underline{151}$ & $\underline{3,236}$ & $\underline{986}$ & $\underline{48,724}$ & $\underline{14,851}$ \\
\hline Summary & 16,827 & & & $3,003,956$ & 915,606 \\
\hline
\end{tabular}


Table 3-Content and description of attributes for the GIS surface effects map databases

[Notes: Listed are field names, descriptions, data types, and examples for all GIS surface effects map themes and bar-andball symbol themes contained in the archive. Example data are given for the Carpetbag (U-2dg) detonation.]

\begin{tabular}{|c|c|c|c|}
\hline Field & Description & Type & $\begin{array}{l}\text { Example } \\
\text { (U-2dg) }\end{array}$ \\
\hline \multicolumn{4}{|c|}{ Attributes of Surface Effects Map Themes } \\
\hline Areaid & NTS Operation Area & Text & Area02 \\
\hline Siteid & $\begin{array}{l}\text { Hole (borehole) name as it appears in the RSN Drilling \& Mining Summary } \\
\text { (Red Book); (Terry, 1990). }\end{array}$ & Text & $\mathrm{U}-2 \mathrm{dg}$ \\
\hline Feature & Surface effects feature type (see Table 2) & Text & Crack \\
\hline Length & Length of surface effects feature, in feet. & Numerical & 256.58 \\
\hline Source & $\begin{array}{l}\text { Original source map for the feature. Used to track the exact source of every } \\
\text { feature. This information is also contained in the surface effects sites } \\
\text { database (se_sites_n27f.shp) as Se_source. }\end{array}$ & Text & $\begin{array}{l}\text { Original } \\
\text { Mylar } \\
\text { U-2dg }\end{array}$ \\
\hline Notes & Note about the individual feature, where necessary. & Text & \\
\hline Label & A label that can be used on display maps, where necessary. & Text & Reactivated \\
\hline \multicolumn{4}{|c|}{$\begin{array}{l}\text { Attributes of Bar-and-Ball Symbol Themes } \\
\text { (Fields are the same as above except for the following) }\end{array}$} \\
\hline Offset_cm & $\begin{array}{l}\text { Vertical offset on fault at location of bar-and-ball symbol, in centimeters. } \\
\text { This field replaces the label field. The } O \text { Offset_cm value is used to label the } \\
\text { bar-and-ball symbols; hence, no label field is needed. The bar-symbol theme } \\
\text { is a line theme. The ball-symbol theme is a point theme. The Offset_cm field } \\
\text { is only used for the ball-symbol theme. }\end{array}$ & Text & 32 \\
\hline
\end{tabular}


Table 4-Content and description of attributes for the GIS surface effects sites database

[Notes: Listed are field names, descriptions, data types, and examples for attributes of the detonation (borehole) sites database (theme se_sites_n27f.shp). Fields $\underline{\text { Sort_id, }} \underline{\text { Bn_seq, }}$ Year, Decade, Date_y2k, Lat27d, Lon27d, Lat83d, Lon83d, Utm83m_n, Utm83m_e and Det_Elev were added to enhance GIS functionality. All added coordinate locations were derived from Northing and Easting locations. Fields containing specific information about the surface effects maps are listed and described in the section entitled "Information Related to the NTS GIS Surface Effects Map Archive" (next page). Specific details about the information content of this database are given. Example data are given for the Carpetbag (U-2dg) detonation.]

\begin{tabular}{|c|c|c|c|}
\hline Field & Description & Type & $\begin{array}{c}\text { Example } \\
\text { (U-2dg) }\end{array}$ \\
\hline \multicolumn{4}{|c|}{ Site Information Derived From And Added To The USGS NTS_UGE Database } \\
\hline Sort_id & $\begin{array}{l}\text { Numerical value used to correctly sort the database by borehole name, as } \\
\text { listed in the field Siteid. }\end{array}$ & Numerical & 93 \\
\hline Bn_seq & Numerical value used to link this database to the BEDIMS database. & Numerical & 9074 \\
\hline Siteid & $\begin{array}{l}\text { Hole (borehole) name as in the RSN Drilling \& Mining Summary (Red } \\
\text { Book); (Terry, 1990). From NTSEVENTS (NTS_UGE) database. }\end{array}$ & Text & $\mathrm{U}-2 \mathrm{dg}$ \\
\hline Name & $\begin{array}{l}\text { Name given to the underground nuclear detonation as reported in } \\
\text { DOE/NV-209 Rev. } 14 \text { (U.S. Department of Energy, 1994). }\end{array}$ & Text & Carpetbag \\
\hline Year & $\begin{array}{l}\text { Year the underground nuclear detonation occurred (yyyy numerical } \\
\text { format). }\end{array}$ & Numerical & 1970 \\
\hline Decade & Decade the underground nuclear detonation occurred (yyyy's text format). & Text & 1970 's \\
\hline Date & $\begin{array}{l}\text { Date of the underground nuclear detonation as reported in DOE/NV } 209 \\
\text { Rev. } 14 \text { (U.S. Department of Energy, 1994) (mm/dd/yy text format). }\end{array}$ & Text & $12 / 17 / 70$ \\
\hline Date_y2k & $\begin{array}{l}\text { Date of the underground nuclear detonation as reported in DOE/NV } 209 \\
\text { Rev. } 14 \text { (U.S. Department of Energy, 1994) (yyyymmdd date format). }\end{array}$ & Date & 19701217 \\
\hline Northing & $\begin{array}{l}\text { Northing (Y-axis) coordinate of site; Nevada State Plane, Central, in feet; } \\
\text { NAD27 datum. }\end{array}$ & Numerical & 866500 \\
\hline Easting & $\begin{array}{l}\text { Easting (X-axis) coordinate of site; Nevada State Plane, Central, in feet; } \\
\text { NAD27 datum. }\end{array}$ & Numerical & 670150 \\
\hline Lat27d & Latitude (geographic) location of site; NAD27 datum; decimal degrees. & Numerical & 37.129130351 \\
\hline Lon27d & Longitude (geographic) location of site; NAD27 datum; decimal degrees. & Numerical & -116.082996179 \\
\hline Lat83d & Latitude (geographic) location of site; NAD83 datum; decimal degrees. & Numerical & 37.129082529 \\
\hline Lon83d & Longitude (geographic) location of site; NAD83 datum; decimal degrees. & Numerical & -116.083867872 \\
\hline Utm83m_n & $\begin{array}{l}\text { Northing (Y-axis) coordinate of site; Universal Transverse Mercator, } \\
\text { Zone 11; NAD83 datum; meters. }\end{array}$ & Numerical & 4109584.79345 \\
\hline Utm83m_e & $\begin{array}{l}\text { Easting (X-axis) coordinate of site; Universal Transverse Mercator, } \\
\text { Zone 11; NAD83 datum; meters. }\end{array}$ & Numerical & 581376.78316 \\
\hline Type & $\begin{array}{l}\text { Emplacement type for the detonation as reported in DOE/NV-209 Rev. } 14 \\
\text { (U.S. Department of Energy, 1994). }\end{array}$ & Text & Shaft \\
\hline Yield & $\begin{array}{l}\text { Yield range for the detonation as reported in DOE/NV-209 Rev. 14: } \\
\text { (U.S. Department of Energy, 1994). }\end{array}$ & Text & $220 \mathrm{kt}$ \\
\hline Grd_Elev & $\begin{array}{l}\text { Ground surface elevation at the borehole location, in feet above mean sea } \\
\text { level; RSN Drilling \& Mining Summary (Red Book); (Terry, 1990). } \\
\text { Value -9999 indicates no data. }\end{array}$ & Numerical & 4302 \\
\hline H_Depth & $\begin{array}{l}\text { Maximum depth of the drill hole, measured from ground level, in feet; } \\
\text { RSN Drilling \& Mining Summary (Red Book); (Terry, 1990). } \\
\text { Value -9999 indicates no data. }\end{array}$ & Numerical & 2270 \\
\hline DOB & $\begin{array}{l}\text { "Depth of Burial" The vertical depth from surface ground zero to the } \\
\text { primary center line, in feet, as per LLNL Containment Database and } \\
\text { LANL Common Event Data System. Value -999 indicates no data. }\end{array}$ & Numerical & 2170 \\
\hline Det_Elev & $\begin{array}{l}\text { Elevation of detonation, in feet above mean sea level. Value calculated as } \\
\text { ["Grd_Elev" minus "DOB"]. Value -9999 indicates no data. }\end{array}$ & Numerical & 2132 \\
\hline
\end{tabular}




\begin{tabular}{|c|c|c|c|}
\hline Field & Description & Type & $\begin{array}{c}\text { Example } \\
\text { (U-2dg) }\end{array}$ \\
\hline \multicolumn{4}{|c|}{ Information Related To The NTS GIS Surface Effects Map Archive } \\
\hline Region & Major physiographic region where site is located. & Text & Yucca Flat \\
\hline Status & $\begin{array}{l}\text { Status of GIS map. This field is used for GIS map status categorization } \\
\text { and for symbol style and color on surface effects map presentations. } \\
\text { Values include: (1) Mapped--Surface Effects, (2) Mapped--No Surface } \\
\text { Effects, and (3) Not Mapped. Sites identified as "Mapped--No Surface } \\
\text { Effects" include detonations that did not produce observable surface } \\
\text { effects and those that exhibited only minor surface effects that were not } \\
\text { formally mapped. }\end{array}$ & Text & $\begin{array}{c}\text { Mapped-- } \\
\text { Surface effects }\end{array}$ \\
\hline Se_map & $\begin{array}{l}\text { Was a surface effects map prepared for this detonation? Values include: } \\
\text { (1) Yes, (2) No, (3) No SE, and (4) None found. "No SE" indicates that a } \\
\text { map would have been produced, but no surface effects were observed (as } \\
\text { in item (2) above). "None found," indicates that a surface effects map may } \\
\text { have been prepared, but the map was not found (10 records). }\end{array}$ & Text & Yes \\
\hline Se_source & $\begin{array}{l}\text { Information about the source map, that is, the original map used to } \\
\text { prepare the GIS surface effects map of the site. There are } 300 \text { unique } \\
\text { entries for mapped sites in the database. }\end{array}$ & Text & $\begin{array}{l}\text { Original Mylar } \\
\text { U-2dg }\end{array}$ \\
\hline Se_scale & $\begin{array}{l}\text { Scale of the source map. The numerical value is the dividend of the scale } \\
\text { ratio. An entry of } 12000 \text { indicates a 1:12,000-scale source map. }\end{array}$ & Numerical & 12000 \\
\hline Se_date & Date that the source map was produced, where known. Blank if unknown. & Date & 19701222 \\
\hline Sink & Did the detonation produce a sink? & Text & Yes \\
\hline Crack & Did the detonation produce cracks? & Text & Yes \\
\hline Fault & Did the detonation produce faults? & Text & Yes \\
\hline P_ridge & Did the detonation produce pressure ridges? & Text & Yes \\
\hline
\end{tabular}




\section{Table 5-Content and structure of the GIS Surface Effects Map Archive on CD-ROM}

[Notes: Listed are folderyilenames, descriptions, data types, and metadata files for principal maps (themes) to illustrate the content and structure of the archive. This table contains representative examples of (1) surface effects maps, crack maps, and mylars for the Yucca Flat and Pahute Mesa testing areas, and (2) basemaps for the NTS, Nevada, and Western United States areas. All surface effects maps and basemaps are in the Nevada State Plane (NAD27) coordinate system, as indicated by their " $n 27 f "$ file suffix and/or folder name. The archive also contains surface effects maps in the Geographic (NAD27), Geographic (NAD83), and UTM (NAD83, Zone 11) coordinate systems, as indicated by "g27d," "g83d," and " $u 83 m$. .]

\begin{tabular}{|c|c|c|c|}
\hline FolderlFilename & Description & Type & Metadata \\
\hline \multicolumn{4}{|c|}{ Yucca Flat Surface Effects Map Themes } \\
\hline \multicolumn{4}{|l|}{ Folder: ...YffselN27f $\backslash$} \\
\hline Yfse_n27f.shp & $\begin{array}{l}\text { Principal composite surface effects maps theme for Yucca } \\
\text { Flat. Contains all surface effects maps. }\end{array}$ & Line & Yfse_metadata.met \\
\hline Yfse_bar_n27f.shp & $\begin{array}{l}\text { Principal composite bar symbols theme for Yucca Flat. } \\
\text { Contains all bar symbols. }\end{array}$ & Line & Yfse_metadata.met \\
\hline Yfse_ball_n27f.shp & $\begin{array}{l}\text { Principal composite ball symbols theme for Yucca Flat. } \\
\text { Contains all ball symbols. }\end{array}$ & Point & Yfse_metadata.met \\
\hline \multicolumn{4}{|l|}{ Folder: ..IYfselN27f(By_Areal } \\
\hline Area02_n27f.shp & $\begin{array}{l}\text { Composite surface effects maps theme for Area } 2 . \\
\text { Theme contains all surface effects maps for Area } 2 .\end{array}$ & Line & Yfse_metadata.met \\
\hline Area02_bar_n27f.shp & $\begin{array}{l}\text { Composite bar symbols theme for Area } 2 . \\
\text { Theme contains all bar symbols for Area } 2 .\end{array}$ & Line & Yfse_metadata.met \\
\hline Area02_ball_n27f.shp & $\begin{array}{l}\text { Composite ball symbols theme for Area } 2 . \\
\text { Theme contains all ball symbols for Area } 2 \text {. }\end{array}$ & Point & Yfse_metadata.met \\
\hline \multicolumn{4}{|c|}{ Others in folder include: Area01 *; Area03*; Area04*; Area06*; Area07*; Area08*; Area09*; and Area10* } \\
\hline \multicolumn{4}{|l|}{ Folder: ...YYfselN27f、By_Sitel } \\
\hline Area02\U-2dg_n27f.shp & Surface effects map for detonation site U-2dg. & Line & Yfse_metadata.met \\
\hline Area02\U-2dg_bar_n27f.shp & Bar symbols theme for detonation site U-2dg. & Line & Yfse_metadata.met \\
\hline Area02lU-2dg_ball_n27f.shp & Ball symbols theme for detonation site U-2dg. & Point & Yfse_metadata.met \\
\hline \multicolumn{4}{|c|}{ Others in folder: All mapped detonations arranged by Area** (folder name) and borehole (siteid, as file name prefix). } \\
\hline \multicolumn{4}{|l|}{ Folder: ..IYfselN27f\Crk_maps \} $\\
{\hline \begin{array}{l}\text { Map1.tif } \\
\text { Map2t.tif } \\
\text { Map2b.tif } \\
\text { Map3.tif }\end{array}} &{\begin{array}{l}\text { Scanned/georeferenced composite maps of surface effects } \\
\text { at Yucca Flat. These are digital reproductions of three, } \\
\text { 1:12,000-scale "crack maps," entitled Map of Explosion- } \\
\text { Induced Features and Bedrock Geology-Yucca Flat (Oct. } \\
\text { 1996). Map sheets (and file names) are listed from north to } \\
\text { south. Map sheet } 2 \text { includes "top" and "bottom" parts } \\
\text { (map2t.tif and map2b.tif). }\end{array}} &{\text { Images }} &{\text { Crk_maps_readme.txt }} \\
{\hline \multicolumn{4}{|l|}{\text { Folder: ..IYfselN27f1Mylars } \backslash}\text { Folder: ..IYfselN27f1Mylars } \backslash} \\
{\hline \text { Area02\U-2dg.tif }} &{\begin{array}{l}\text { Scanned/georeferenced copy of original U-2dg surface } \\
\text { effects map. U-2dg is used as an example. }\end{array}} &{\text { Image }} &{\text { None }} \\
{\hline \multicolumn{4}{|c|}{\text { Others in folder: All mapped detonations arranged by Area** (folder name) and borehole (siteid, as file name prefix). }}\text { Others in folder: All mapped detonations arranged by Area** (folder name) and borehole (siteid, as file name prefix). }} \\
{\hline \multicolumn{4}{|c|}{\text { Pahute Mesa Surface Effects Map Themes }}\text { Pahute Mesa Surface Effects Map Themes }} \\
{\hline \multicolumn{4}{|l|}{\text { Folder: ...PmselN27f } \backslash}\text { Folder: ...PmselN27f } \backslash} \\
{\hline \text { Pmse_n27f.shp }} &{\begin{array}{l}\text { Principal composite surface effects maps theme for } \\
\text { Pahute Mesa. Contains all surface effects maps. }\end{array}} &{\text { Line }} &{\text { Pmse_metadata.met }} \\
{\hline \text { Pmse_bar_n27f.shp }} &{\begin{array}{l}\text { Principal composite bar symbols theme for Pahute Mesa. } \\
\text { Contains all bar symbols. }\end{array}} &{\text { Line }} &{\text { Pmse_metadata.met }} \\
{\hline \text { Pmse_ball_n27f.shp }} &{\begin{array}{l}\text { Principal composite ball symbols theme for Pahute Mesa. } \\
\text { Contains all ball symbols. }\end{array}} &{\text { Point }} &{\text { Pmse_metadata.met }} \\
$\hline}
\end{tabular}




\begin{tabular}{|c|c|c|c|}
\hline FolderlFilename & Description & Type & Metadata \\
\hline \multicolumn{4}{|l|}{ Folder: ..IPmselN27flBy_Areal } \\
\hline Area19_n27f.shp & $\begin{array}{l}\text { Composite surface effects maps theme for Area } 19 . \\
\text { Contains all surface effects maps for Area } 19 .\end{array}$ & Line & Pmse_metadata.met \\
\hline Area19_bar_n27f.shp & Composite bar symbols theme for Area 19. & Line & Pmse_metadata.met \\
\hline Area19_ball_n27f.shp & Composite ball symbols theme for Area 19. & Point & Pmse_metadata.met \\
\hline \multicolumn{4}{|c|}{ Others in folder include: Area20_n27f.shp; Area20_bar_n27f.shp; and Area20_ball_n27f.shp } \\
\hline \multicolumn{4}{|l|}{ Folder: ...PmselN27f(By_Sitel } \\
\hline Area19\U-19b_n27f.shp & Surface effects map of detonation site U-19b. & Line & Pmse_metadata.met \\
\hline Area19\U-19b_bar_n27f.shp & Bar symbol theme for detonation site U-19b. & Line & Pmse_metadata.met \\
\hline Area19\U-19b_ball_n27f.shp & Ball symbol theme for detonation site U-19b. & Point & Pmse_metadata.met \\
\hline \multicolumn{4}{|c|}{ Others in folder: All mapped detonations arranged by Area** (folder name) and borehole (siteid, as file name prefix). } \\
\hline \multicolumn{4}{|l|}{ Folder: ...PmselN27f1Mylars } \\
\hline Area19\U-19b.tif & $\begin{array}{l}\text { Scanned/georeferenced copy of original U-19b surface } \\
\text { effects map. U-19b is used as an example. }\end{array}$ & Image & None \\
\hline
\end{tabular}

\begin{tabular}{|c|c|c|c|}
\hline \multicolumn{4}{|c|}{ NTS Basemap Themes } \\
\hline \multicolumn{4}{|l|}{ Folder: ..|Basemaps\NTS $\backslash$} \\
\hline Areasınts_areas_poly.shp & NTS administrative (operational area) boundaries & Polygon & nts_areas_poly.met \\
\hline Areas\nts_areas_line.shp & NTS administrative (operational area) boundaries & Line & nts_areas_poly.met \\
\hline Borderlnts_border_poly.shp & NTS boundary extracted from nts_areas_poly.shp & Polygon & None \\
\hline ContoursInts_contours_50m.shp & Topographic contour map; 50-meter interval & Line & nts_contours_50m.met \\
\hline DEM10mldem10m_n27f.tif & Shaded relief map prepared from radar imagery & Image & dem10m_readme.txt \\
\hline DEM10m\nts-mask_poly.shp & Polygon mask to trim dem10m_27f.tif at NTS border & Polygon & None \\
\hline Gridlnts_2500ft_n27f.shp & 2,500-foot grid prepared directly from numerical data & Line & None \\
\hline LakesInts_lakes_poly.shp & Lakes and playa lakes polygon theme & Polygon & nts_lakes_poly.met \\
\hline Quadsınts_quads_n27f.shp & $\begin{array}{l}\text { Boundaries of 1:24,000-scale USGS topographic quads } \\
\text { for the NTS (from western US theme, below). }\end{array}$ & Polygon & None \\
\hline Roads\nts_roads.shp & Primary and secondary roads and trails (TIGER) & Line & nts_roads.met \\
\hline Streams Ints_streams.shp & Perennial and ephemeral streams & Line & nts_streams.met \\
\hline
\end{tabular}

\begin{tabular}{|l|l|c|c|}
\hline \multicolumn{3}{|c|}{ Nevada Basemap Themes } \\
\hline Folder: ...Basemaps\Nevada\ & $\begin{array}{l}\text { Boundary theme of 1:24,000-scale USGS topographic } \\
\text { quadrangle maps of Nevada; extracted from the western } \\
\text { US theme (below). }\end{array}$ & Polygon & None \\
\hline Quads\nv_quads_n27f.shp
\end{tabular}

\begin{tabular}{|l|l|l|c|}
\hline \multicolumn{4}{|c|}{ Western United States Basemap Themes } \\
\hline Folder: ..IBasemaps\Western_US $\backslash$ & $\begin{array}{l}\text { Polygon } \\
\text { Boundaries of 1:24,000-scale USGS topographic quads } \\
\text { for the Western United States. Contains quad borders } \\
\text { (polygons) and quad names (attributes). }\end{array}$ & None \\
\hline Stateslw-states_n27f.shp & $\begin{array}{l}\text { State boundaries for Western United States. Contains } \\
\text { state boundaries (polygons) and state names (attributes). }\end{array}$ & Polygon & None \\
\hline
\end{tabular}




\subsection{Glossary}

The following features are commonly observed surface effects of underground nuclear testing at the Nevada Test Site. These definitions were compiled from a variety of sources including Allen and others, 1997; Garcia, 1997; Houser, 1970; Drellack, 1988; and Garcia, Drellack, and McKinnis, [unpublished data].

Collapse sink (or sink): A topographic depression caused by surface subsidence within the chimney above an underground nuclear detonation, at or near surface ground zero. Often informally referred to as a crater at the Nevada Test Site, collapse sinks are distinct from craters in that there is no throw-out or vaporization of surface materials.

Crack (or fracture): A break or parting of the ground surface caused by an explosion-induced mechanical failure of the geologic surface material. Cracks generally range from "hairline" to several tens of centimeters in width, and from several centimeters to several hundreds of meters in length. The largest cracks are usually associated with the highestyield detonations and/or nearby faults (Allen and others, 1997, p. 29). In the context of surface effects mapping, a crack that has a limited vertical extent below the ground surface is referred to as a fracture. However, because this distinction was not made on the original surface effects maps, the words crack and fracture are used synonymously in this report. The following types of fractures (cracks) are present in Yucca Flat and Pahute Mesa.

- Concentric fracture: Surface fractures that form in a circular orientation around surface ground zero of an underground explosion.

- Hairline fracture: Surface fractures that have a width (aperture) of less than $3 \mathrm{~mm}$. Hairline fractures tend to form on prepared surfaces, such as roads.

- Linear fracture: Surface fractures that form in a series (or trend) of discontinuous, en echelon, parallel, or sub-parallel linear features.

- Radial fracture: Surface fractures oriented in a "spoke-like" pattern around surface ground zero.

- Reactivated fracture: A pre-existing fracture on which failure recurs during a subsequent detonation.

- Random fracture: Small-scale movement along pre-existing block joints in the underlying rock or in the surface rock sometimes called "Block Chatter". The results of these movements may appear random or in a mosaic pattern.

Crater: A topographic depression caused by an explosion at or near the surface that forms as a result of compaction, throw-out (ejecta), and/or vaporization of surface materials. The largest craters were produced in Yucca Flat and Pahute Mesa as the result of excavation experiments in the 1960's under the Plowshare Program. These include the 1962 Sedan crater, located at the northern end of Yucca Flat, and the 1968 Schooner crater located in the northwest corner of Area 20 on Pahute Mesa.

Fault: An extensive fracture caused by an underground detonation along which vertical and/or horizontal displacement has occurred. Although a fault is commonly referred to in the 
singular, the largest faults of Yucca Flat and Pahute Mesa (e.g., Yucca Fault, Carpetbag Fault, and other named and unnamed faults) consist of several parallel, braided, and en echelon faults that form fault or fracture zones.

Pressure ridge: A low, narrow topographic ridge raised above the ground surface by compressional stresses resulting from an underground detonation. Pressure ridges are typically straight to slightly curved or locally sinuous.

Surface effect: A stress-induced surface feature caused by an underground nuclear detonation.

Surface Ground Zero (SGZ): That point on the ground surface that is located directly above an underground nuclear detonation. 